\title{
Italy: toward a growth-friendly fiscal reform
}

\author{
Michal Andrle $^{1} \cdot$ Shafik Hebous $^{1} \cdot$ Alvar Kangur $^{1} \cdot$ Mehdi Raissi $^{1}$
}

Received: 30 April 2018 / Accepted: 11 August 2020 / Published online: 16 September 2020

C Springer Nature Switzerland AG 2020

\begin{abstract}
Published in late 2017, the Italian medium-term fiscal plan aims to achieve structural balance by 2020 , although concrete, high-quality measures to meet the target are yet to be specified. This paper seeks to contribute to the discussion by (1) assessing spending patterns to identify areas for savings; (2) evaluating the pension system; (3) analyzing the scope for revenue rebalancing; and (4) putting forward a package of spending cuts and tax rebalancing that is growth friendly and inclusive, could have limited near-term output costs, and would achieve a notable reduction in public debt over the medium term. Such a package could help the authorities balance the need to bring down public debt and, thus, reduce vulnerabilities while supporting the economic recovery.
\end{abstract}

Keywords Fiscal reform · Growth-friendly fiscal policy $\cdot$ Public pensions · Italy

JEL Classification E27 $\cdot$ E62 $\cdot$ H55

\section{Introduction}

Italy has been struggling with low economic growth since the 1990s. Productivity growth has been persistently anemic and has lagged that of the euro area-see Anderson and Raissi (2018), Andrle et al. (2018), Bugamelli and Lotti (2018) and the references therein.

Held back by long-standing rigidities, the economy failed to take advantage of euro accession to modernize its institutions or adapt to a changing global trade and technological landscape. Pellegrino and Zingales (2017) attribute the weak productivity growth in Italy to the lack of meritocracy in the selection and rewarding of managers, and the inability of firms to take full advantage of the information and communication technology revolution. Akcigit et al. (2018) argue that political connections adversely affected firm dynamics, innovation, and creative destruction in

Shafik Hebous

shebous@imf.org

1 International Monetary Fund, 700 19th St NW, 20341 Washington, DC, USA 
Italy, weighing on the economic growth. Moreover, wage growth outpaced productivity growth, contributing to high structural unemployment; see Kangur (2018). Easy access to finance pre-crisis boosted demand, but the double-dip recession earlier this decade and the subsequent tightening of credit conditions set Italy back further; see Doerr et al. (2018), and Mohaddes et al. (2017). Implementing structural reforms are, thus, of greatest importance.

High public debt and an inadequate composition of fiscal policy have also contributed to Italy's underperformance. Public debt, above 130\% of GDP and the second highest in Europe, has been a perennial source of vulnerability - see Reinhart and Rogoff (2010) and Chudik et al. (2013, 2017) who consider the consequences of high and rising public debt on economic growth. Italy has run primary fiscal surpluses that on average were higher than its euro area peers, but these were insufficient to lower debt and secure stability. The quality of fiscal policy has also insufficiently supported inclusive growth. The burden of high taxes has fallen on labor, public investment has been squeezed, and social benefits have centered on generous pensions. Aiming for an adequate primary surplus to reduce debt, underpinned by high quality pro-growth and inclusive measures, is thus also important.

This paper contributes to the debate by identifying growth-friendly and inclusive options for achieving fiscal balance that could potentially put Italy's public debt on a firm downward path. Firstly, it discusses public spending trends and composition. An analysis of spending over the past two decades reveals that: (1) in the decade following euro accession, spending grew faster than potential output, owing in large part to the rapid growth of pensions; (2) since the global financial crisis, spending has been broadly controlled, mainly through a freeze on hiring and wages and cuts in capital spending. Pension spending though has continued to rise; (3) despite the recent spending control, the pre-crisis spending excesses have not been reversed; and (4) achieving sizable and durable expenditure savings may require lowering the large pension spending. Improving the efficiency of health spending in some geographical areas could also lead to some savings.

Secondly, the paper analyzes the Italian pension system. Over half of current primary spending is social benefit expenditure, which is dominated by pension spending. At around $16 \%$ of GDP, pension spending in Italy is the second highest in the euro area after Greece. The Italian authorities have legislated several reforms in the past. However, before the full effect of these reforms is evident over the very long run, fiscal pressures are likely to persist and weigh on Italy's goal of achieving and maintaining a balanced budget. The second part of this paper finds that: (1) despite past reforms, there remain generous parts of the system where Italy is an outlier, pointing to areas of potential savings; and (2) pension projections rest on optimistic assumptions of (a) employment, specifically that Italy will go from having among the highest to very low unemployment rates; and (b) Italy will maintain much higher real GDP growth rates for decades to come than has been its experience and policy settings. Relaxing these assumptions implies a notable rise in projected spending over the coming decades until the full benefits of past reforms become evident.

Thirdly, drawing lessons from the literature and cross-country experience, it discusses options for revenue rebalancing in Italy. The tax system is characterized by a high tax wedge, a relatively narrow tax base, and significant tax arrears. A fiscal 
devaluation strategy - a shift from taxing productive factors to taxing consumption and property-reveals the scope to (1) decrease the tax wedge significantly; (2) reduce value-added tax gaps (both compliance and policy), by harmonizing the reduced VAT rates and improving the tax collection performance; (3) rationalize tax expenditures; and (4) raise revenues by re-introducing a modern property tax on primary residences.

Fourthly, it simulates, using the IMF's Global Integrated Monetary and Fiscal (GIMF) model, the impact of a growth-friendly and inclusive mix of spending and revenue measures along a gradual fiscal consolidation path that puts Italy's debt-toGDP ratio on a firm downward trajectory - see Kumhof et al. (2010) and Anderson et al. (2013) for modeling details. The model simulations show that a revenue-neutral and less distortionary tax reform, alongside current spending cuts and capital spending increases, can generate sizable output gains and a sustainably lower public debt ratio over the medium to long term. Short-term output costs of this fiscal package, if implemented credibly, are likely limited.

The rest of the paper is organized as follows. Section 2 discusses Italy's public spending trends and composition. Section 3 analyzes the pension system and identifies certain areas that can be improved. Section 4 considers some options for revenue rebalancing. Section 5 conducts a simulation exercise to assess the macroeconomic effects of a growth-friendly mix of spending and revenue measures. Section 6 concludes.

\section{Public spending trends and composition}

Over the past two decades, primary spending in Italy has grown faster than potential output. This was particularly the case in the years after euro accession. From 1999 to 2007, Italy's nominal current primary expenditure grew faster than the euro area average, and well above the country's average nominal potential growth-driven mainly by social benefit spending (primarily pensions), intermediate consumption (goods and services), and wages (in general services, defense and health). Capital spending rose in line with that of the euro area average. From 2008 to 2016, however, Italy's nominal current primary expenditure grew at $1.8 \%$ per year on average, below the euro area average of $2.6 \% .^{1}$ The deceleration after the global financial crisis was driven mainly by the decline in the public sector wage bill-reflecting the freezing of nominal wages from 2010 to 2015 and a reduction in the number of public sector employees from 3.6 million in 2007 to around 3.3 million people in 2015; and a severe cut in capital expenditure, which declined by about $28 \%$ in nominal terms between 2009 and 2016. Nevertheless, even with these exceptional measures, total primary spending grew above the country's average nominal potential GDP growth over this period. Italy has been unable to reverse its past overspending (especially those related to the pre-crisis period).

\footnotetext{
${ }^{1}$ The high cost of servicing public debt implies total public expenditure in Italy about $2 \%$ of GDP above the euro area average (at $50.4 \%$ of GDP versus $48.5 \%$ ). Interest on debt (4.2\% of GDP in 2015) absorbs more resources than spending on education ( $4 \%$ of GDP), and is over $3 \frac{1}{2}$ times as much as on defense (1.2\% of GDP).
} 


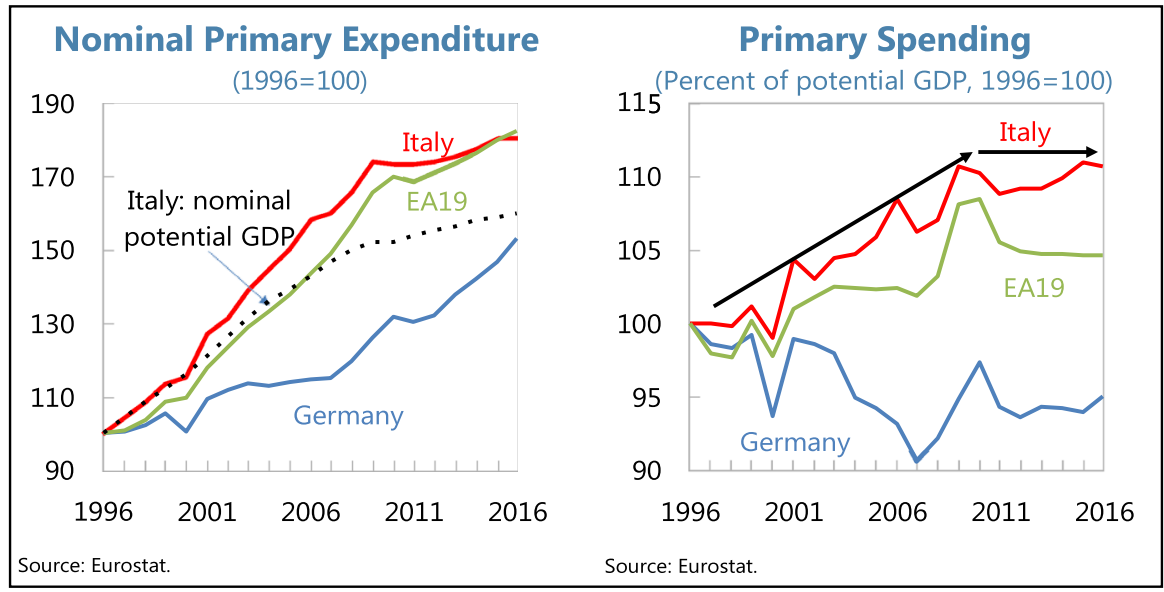

Social benefits have dominated all other categories of spending, rising by about 43\% cumulatively from 1999 to 2007 and by a further 33\% since then. It constitutes half of total primary spending, up from $40 \%$ at the time of euro accession. The bulk of social benefits spending is in pensions (see Sect. 3), reflecting both a high share of elderly population and generous pension benefits. However, non-pension social benefit spending in Italy is low, fragmented, and poorly targeted in comparison to other EU countries. The latter is evidenced in the disproportionately low share of social transfers accruing to the low-income working age population. There is also a higher reliance on intra-family transfers for social assistance, even as there is underspending related to social inclusion, family/child benefits, and housing relative to the euro area average.

A decomposition of spending-using standard economic and functional classifications at the general government levels (Table 1) -reveals that, apart from pensions: (1) interest payments exceed the euro area average by $1.6 \%$ of GDP, given Italy's high stock of public debt. (2) Other areas of overspending include intermediate consumption spending (primarily on goods and services) in the health sector; compensation of employees in defense, public order and safety, and health; subsidies in the economic affairs sector; and capital transfers in general services and economic affairs. (3) It is notable that although overall public health spending in Italy is in line with the euro area average, the bulk of it is for compensation of employees and intermediate consumption, in contrast with the euro area average where the share of spending on these two items is significantly lower and that of expenditure on provision of other social benefits is $50 \%$ higher. This points to room for potential efficiency savings, especially in some regions. ${ }^{2}$ Medeiros and Schwierz (2015)

\footnotetext{
2 An outline for the rules of fiscal federalism was approved by parliament in 2009, but much of the detail related to standard costs has yet to be agreed. The only part operating in practice is the system for calculating central finance for health expenditure and for municipalities, per an increasing share of total grants. From 2017 , the use of expenditure needs, and standard tax capacity is also used as a criterion to set consolidation targets for ordinary statutory regions and autonomous provinces. Health expenditure accounts for around half of sub- national government spending. For regional administrations, it accounts for about $85 \%$ of spending.
} 


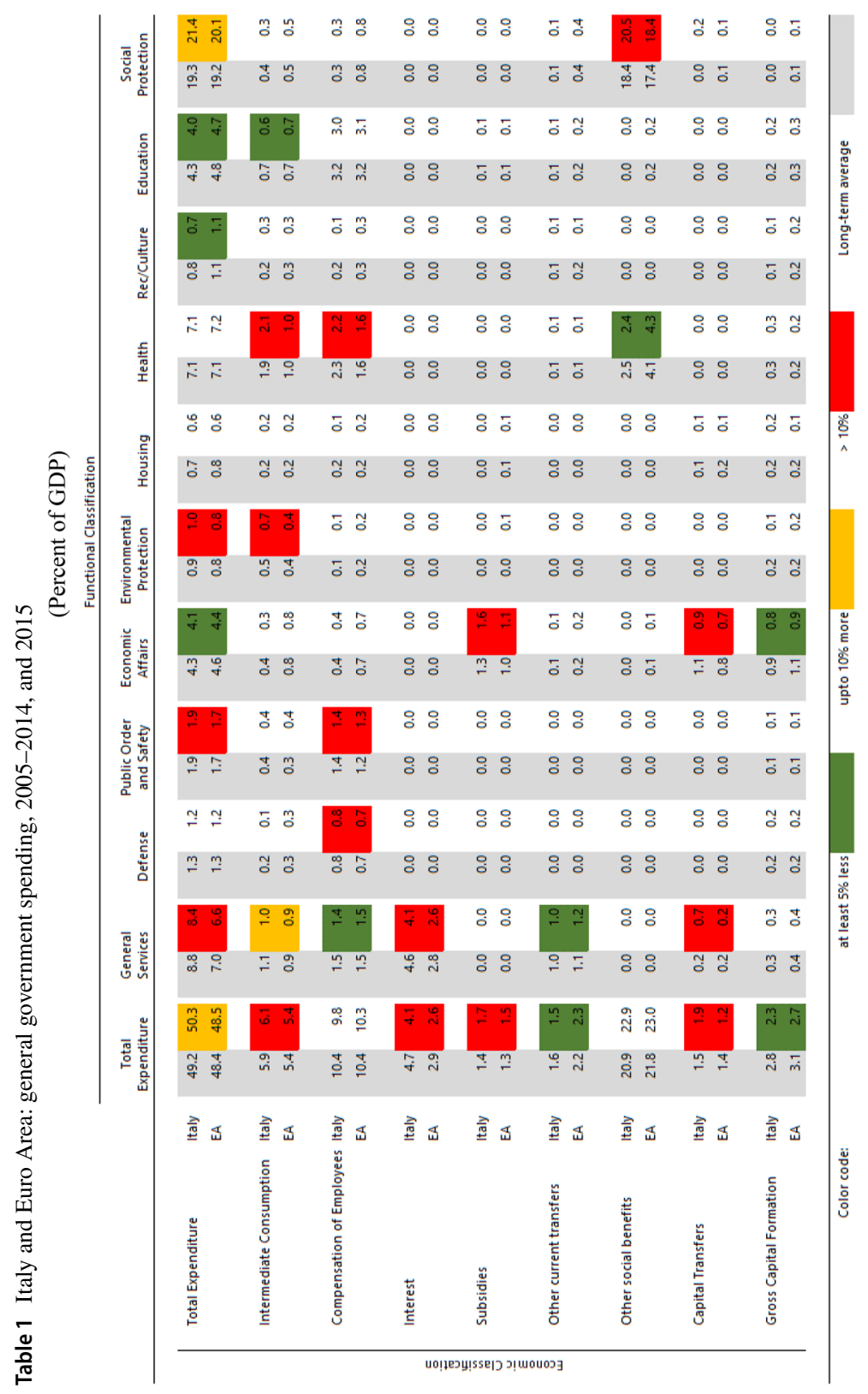


highlight regional differences and show that the output of public spending is lower in southern regions based on health-related variables, such as life expectancy at the age of 65. (4) The main areas where Italy underspends is in education (i.e., in the provision of goods and services and in total compensation). The public education expenditure gap is especially concentrated at the tertiary level, as highlighted in OECD $(2015 a, b)$. As for economic classification, underspending is largely in gross capital formation (Fig. 1).

There is, therefore, room to improve the spending mix to make it more growth friendly and inclusive. The above simple presentation indicates that rising social spending (primarily pensions) has crowded out spending in areas such as education and capital spending. Achieving a more growth-friendly and inclusive spending policy mix, while making space to achieve the medium-term objective, will likely require rationalizing total social benefit spending; rationalization of non-pension social benefit spending; better efficiency in health spending in some regions; and reallocation of spending toward capital spending and education, while also improving the efficiency of outcomes in both areas. Protection of the vulnerable could be further improved through complementary measures such as more intense use of active labor market policies and a modern social safety net; see IMF (2019) for a proposal.

Following sharp cuts in capital spending and with the wage bill/GDP at its lowest in two decades, rationalizing social benefits spending appears unavoidable. In recent years, the authorities have pursued a strategy of notably cutting capital spending and curtailing the wage bill, which at $9.8 \%$ of GDP is at its lowest level in several years. This strategy may be close to its limit, however, and may be neither sustainable nor desirable. There is a need for public investment to support stronger, sustained growth. ${ }^{3}$ Moreover, as a share of total employment, public sector employment is below the euro area average; the age structure of public employees is titled toward older workers, implying the need to refresh the skill mix without reducing the headcount further (there have been recent announcements for hiring sizable numbers of new staff, in education and local offices); and, after years of wage freezes, wage increases are planned. ${ }^{4}$ This suggests limited room, if any, for further cuts in the overall wage bill or in capital spending, going forward, and thus for little alternative but to tackle the sizable social benefits spending (Fig. 2).

\footnotetext{
${ }^{3}$ OECD $(2015 a, b)$ argues that public investment in Italy is inefficient owing to overlapping responsibilities between levels of government, insufficient attention to cost effectiveness in the selection of projects and in implementation, and the lack of technical capacity in evaluation and implementation. The Bank of Italy (2012) also highlights higher unit costs and slower delivery on road and rail projects, adjusting for objective differences, than in other European countries.

4 The wage freeze was put in place when the economy went into a deep recession and has remained through a period of weak nominal growth. To keep it broadly in place when stronger nominal growth is expected could be difficult, not least as the constitutional court has also noted that wage increases need to be given.
} 
Public Administration Employment

(Percent of total)
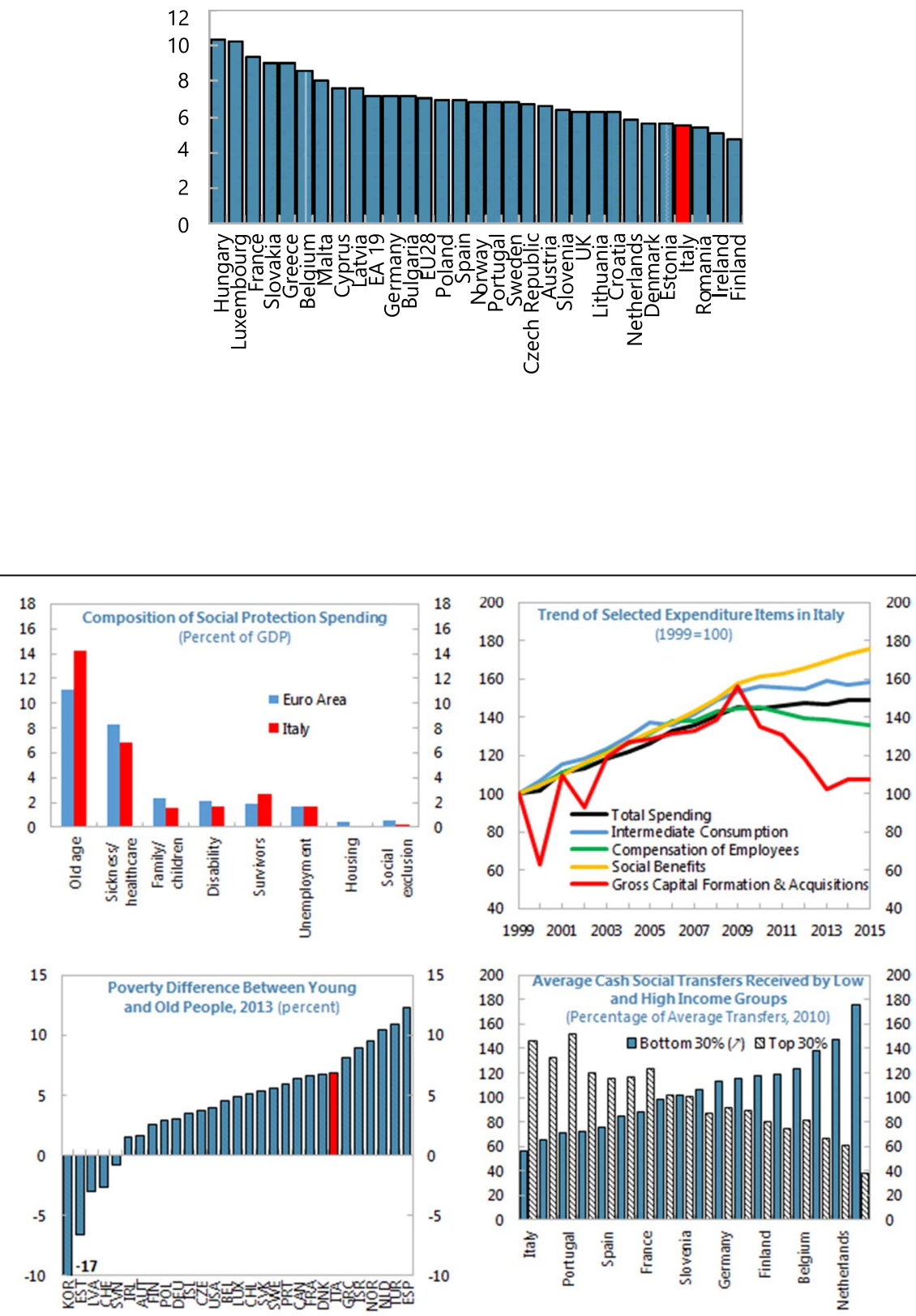

Source: Eurostat, Haver, OECD, and IMF staff.

Fig. 1 Italy: social benefits 


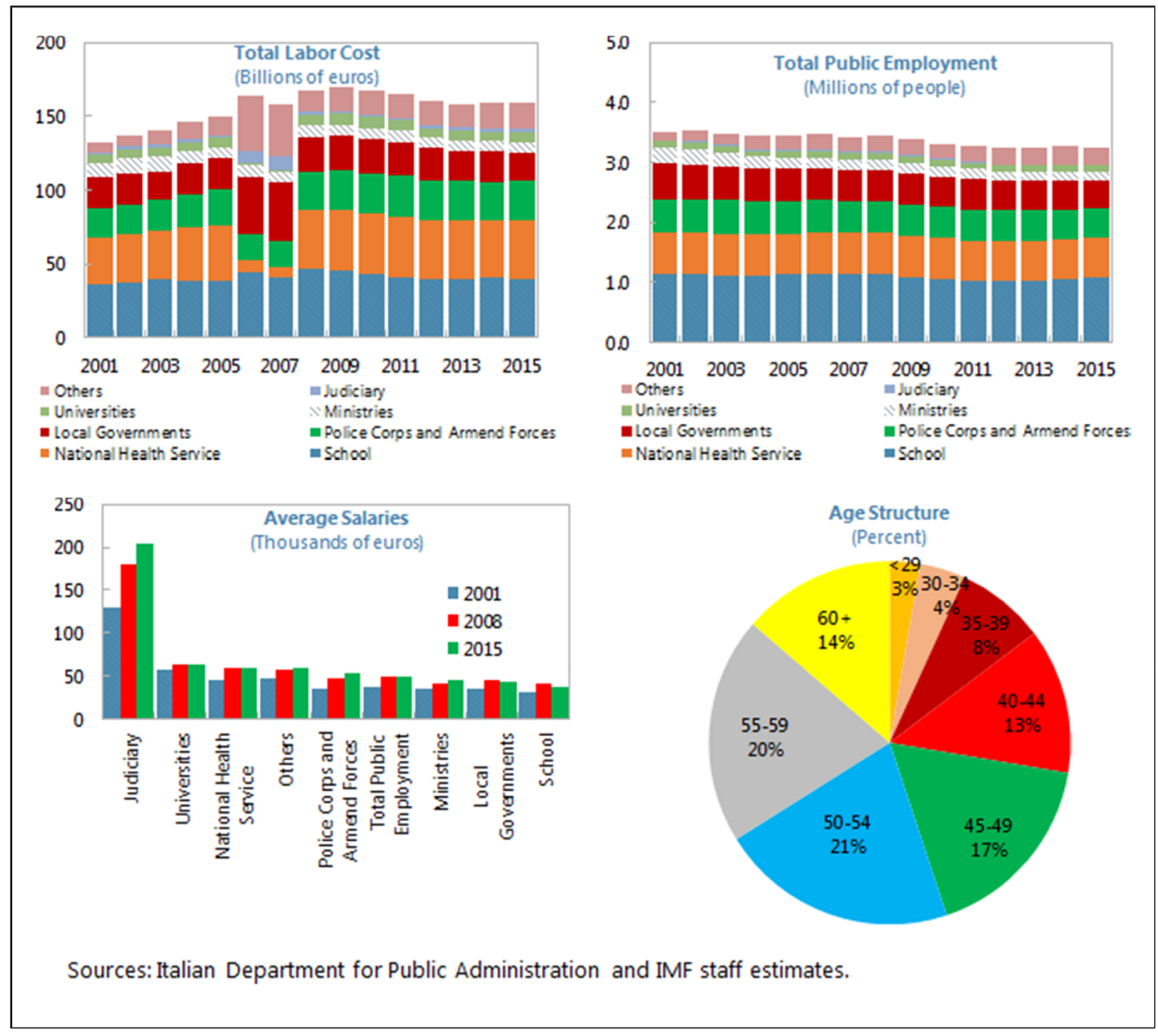

Fig. 2 Italy: dimension of the civil service workforce

\section{The Italian pension system: a deeper look}

\subsection{Past reforms and the current system}

Since 1992, the Italian pension system has undergone multiple reforms. These include pro-rata replacement of the old Defined Benefit (DB) scheme with a Notional Defined Contribution (NDC) scheme (1995, tightening of eligibility requirements (1992, 1995, 1997, 2004, 2007, 2011), alignment of the statutory retirement age of women with that for men $(2010,2011)$, and indexation of the retirement age to life expectancy.

The transition from the old DB system to an NDC scheme divides pension beneficiaries into two categories: (1) those with at least 18 years of contributions by end1995 will largely maintain the DB formula. For this group, the old pension rules are grandfathered for contributions accumulated until 2011. For contributions accrued after 2011, the NDC scheme applies. (2) Those with less than 18 years of contributions by end-1995 are subject to a pro-rated scheme. For this group, contributions accumulated up to 1995 will be subject to the DB formula, whereas contributions 
accumulated after 1995 will be subject to the NDC scheme. The average contribution period in Italy for new pensions is about 33 years (expected to increase to 35 years) and life expectancy at 65 is about 20 years. Thus, by about 2030, all new retirees entering the pension system will be fully subject to the NDC formula, whereas by about 2050 , the old DB should be fully phased out also from the stock of existing retirees.

Eligibility requirements have been tightened considerably in a series of reforms, notwithstanding repeated attempts to weaken them. Both statutory and early retirement ages are set to increase further over time as part of the 'Fornero' reform (L. 214/2011). ${ }^{5}$ Currently, the Statutory Retirement Age (SRA) is 66 years and 7 months. Early Retirement is allowed regardless of age based on minimum years of service of 42-43 years. Under NDC, workers may retire up to 3 years earlier than the SRA with minimum 20 years of contributions and a pension of at least $€ 1200$ per month. From 2013 onwards, the eligibility requirements are linked to changes in life expectancy at 65 (every 3 years up to 2019 and 2 years starting from 2021). Occasionally, pathways to early retirements were eased or implementation of stricter rules were postponed (e.g., the 2017 and 2019 budgets). The experimental "Quota 100 " early retirement rule, introduced in 2019 , created a discontinuity in the retirement age that needs to be addressed. ${ }^{6}$ In general, special treatments and incentives for early withdrawal from the labor market should be avoided in both DB and NDC schemes (see also IMF 2010).

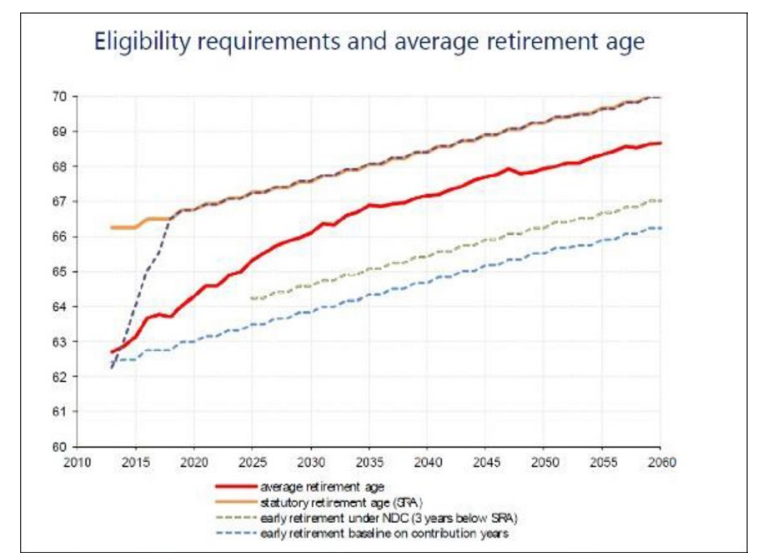

\footnotetext{
5 Following the 'Fornero' reform, the pension system (1) adopts an actuarial computation of pension benefits using an implicit rate based on the accrued contributions, and automatically adjusted to mortality developments; and (2) introduces periodic increases in all eligibility requirements in line with longevity developments.

6 According to the Quota 100 rule, workers who are at least 62 years of age with a minimum 38 years of contributions are eligible for early retirement during 2019-21. Women who are at least 59 years of age with a minimum 35 years of contributions are also eligible. Automatic adjustments of the statutory retirement age to life expectancy were canceled for 2019-20.
} 


\section{Issues}

The existing DB scheme is overly generous on many accounts: (1) it uses a weighted average accrual rate of $2 \%$ (MEF 2014) that is multiplied by the years of contributions and the reference wage (pensionable earnings) to obtain the monthly pension benefit. An accrual rate of $2 \%$ is high by international comparison, compared to about 1.5-1.7\% in the EU/euro area. (2) For insurance years before 1992, the reference wage is defined as the last monthly wage for civil servants or an average wage of the last 5-10 years in the private sector, based on different sources and occupations. For contribution years after 1992, the number of annual wages involved in the calculation increases gradually until it covers the last 10 years for employees and the last 15 years for the self-employed. But the periods over which pensionable earnings are calculated are still too short and tend to inflate the pension benefits of the DB scheme. On the other hand, the NDC (by definition) covers total lifetime contributions. Under the DB scheme, the early retirement penalty is $1 \%$ at the age of $61,2 \%$ at the age of 60 , and a further 2 p.p. for each year below 60. These penalties are rather lenient-Queisser and Whitehouse (2006) calculate that, for Italy, the actuarially neutral reduction in benefits for each year of early retirement is in the order of $7.5 \%$.

As a result, the replacement rates under the current DB/mixed scheme are high compared to other countries and place the adjustment burden disproportionately on future retirees (chart). The difference from the euro area average, according to European Commission (2015), is around $10 \%$ points. The simplest solution would be to reduce spending in $\mathrm{DB} /$ mixed schemes equivalent to the thirteenth pension payment (i.e., the Christmas bonus) that would constitute a $7.7 \%$ cut in average pensions of the DB component. ${ }^{7}$ Another option that would improve intergenerational fairness is to recalibrate existing pensions based on the steady-state NDC formula or equivalent accrual rates.

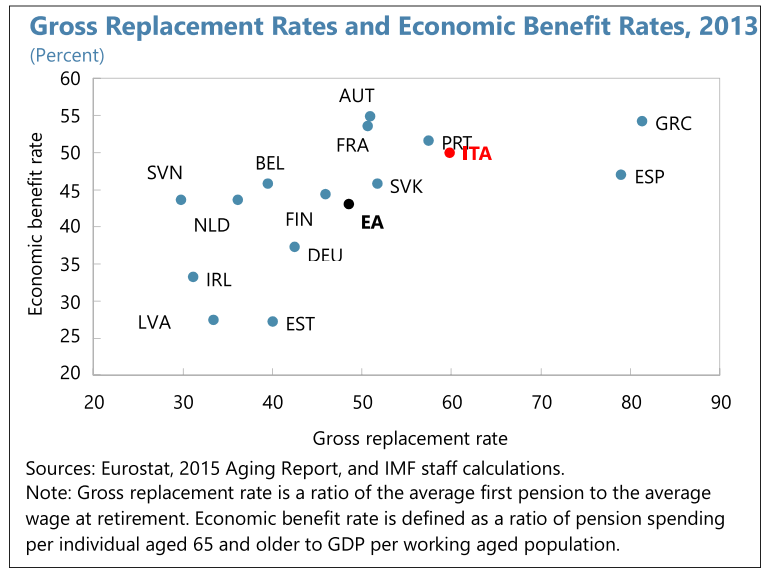

\footnotetext{
7 In the NDC scheme, it should be noted, however, that the thirteenth payment by itself does not constitute a departure from actuarial fairness since the calculation of the annuity considers 13 payments.
} 
Regarding the NDC scheme, although it can screen out many past excesses, ${ }^{8}$ the annuity factor is based on a too high internal rate of return (IRR). In a "pure" NDC, the IRR should be chosen to ensure actuarial balance between the system-wide assets and liabilities ("Annex"). In steady state, the IRR converges to the rate of economic growth. ${ }^{9}$ While in the Italian NDC the IRR that credits the notional capital each period is the moving average of nominal GDP growth over the past 5 years, the discount rate used to derive the annuity factor, defined as the ratio of the IRR to a rate of inflation indexing, is set at a rate of $1.5 \%$, based on an expected longrun real growth rate. ${ }^{10}$ Absent comprehensive and decisive structural reforms, such a real rate of return is considerably above Italy's current growth potential. In the Italian pension system, the adjustment to macro-demographic conditions (such as the periodic revisions in the transformation coefficient) affect future generations of retirees only, leaving current retirees unaffected. The IRR that credits the notional capital is linked to past performance. It would therefore be important to introduce an automatic adjustment (or sustainability) factor that links current pension payments to a measure of a long-term actuarial balance to shield against unforeseen shocks and improve intergenerational equity (see Barr and Diamond, 2011, for a discussion on such a "break" mechanism in Sweden).

At around $23 \%$ of GDP, spending on survivor pensions is the highest in the Europe. According to Eurostat, the average monthly survivors benefit per inhabitant (at constant prices) in Italy was $€ 608$ compared to about $€ 500$ in the euro area in 2014 - the second highest in the euro area after Luxembourg and the third highest in Europe after Luxembourg and Denmark. Similarly, survivor pensions in Italy have very wide coverage: the number of survivor pensions forms about $28 \%$ of total pensions in Italy and is much higher compared to about $18 \%$ in the EU on average. The eligibility for a surviving spouse in Italy does not appear to be constrained by an age limit, the absence of which can also dis-incentivize return to the labor market, especially for women. Survivor pension payments to family members other than surviving spouse or orphans should be strictly limited. ${ }^{11}$

\footnotetext{
${ }^{8}$ The NDC is based on the total lifetime earnings history instead of the average of the last few years; cuts benefits (and thus implicit accrual rates) automatically in case of lower contribution rates/payments or demographic shocks; and thus also ensures neutral adjustment factors (implicit early retirement penalties). However, this is not to say the NDC is automatically sustainable or not open to interference that can operate via different sets of parameters (e.g., fourteenth pension, annuity factor). As in any PAYGfinanced system, sustainability also depends on demographic trends and whether growth and employment outcomes materialize as currently parameterized (see the next subsection).

${ }^{9}$ Here we abstract from the adjustment factor derived by Settergren and Mikula (2006) that can arise in non- steady state and in practice captures payment timing and system noise.

10 A higher discount factor leads to a lower annuity factor, increasing the calculated annuity at retirement.

11 SSA (2016) documents that $15 \%$ of the old-age or disability pension is paid to each parent, brother, or sister if there is no surviving spouse or orphans.
} 


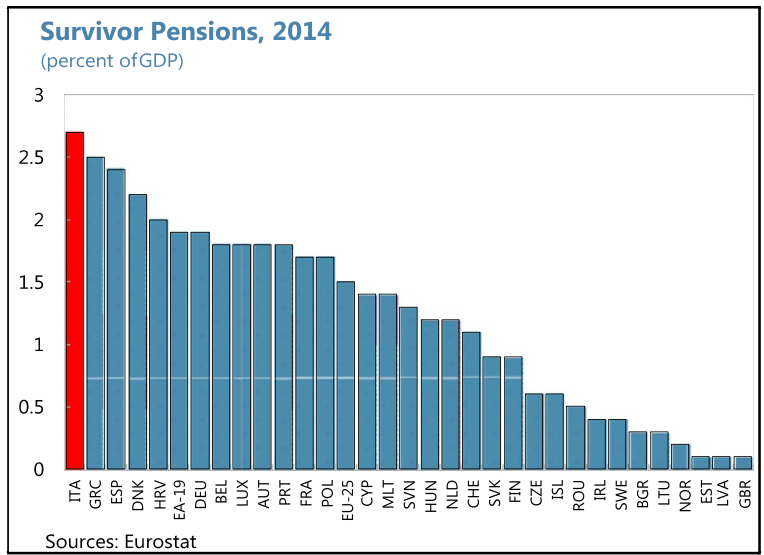

Revenues collected from the self-employed could be increased. At $33 \%$, the pension contribution rates on wage earners are high. Of the contribution rates on wage earners, about one-third is borne by the employee and two-thirds by the employer. For the self-employed and farmers, the contribution rate in 2014 was $22.2 \%$, set to increase to $24 \%$ by 2018 . One explanation for the difference in the contribution rates for employees and self-employed relates to differences in the gross base: for the selfemployed, the gross contribution base includes all contributions whereas for workers only one-third (the employees' share). However, even then, the "neutral" contribution rate for the self-employed should be at least $27 \% .^{12}$ The self-employed in Italy exhibit below average revenue productivity compared to their peers in the euro area. This is indicative of the need to further harmonize the contribution rates as well as strengthen collection and payment compliance.

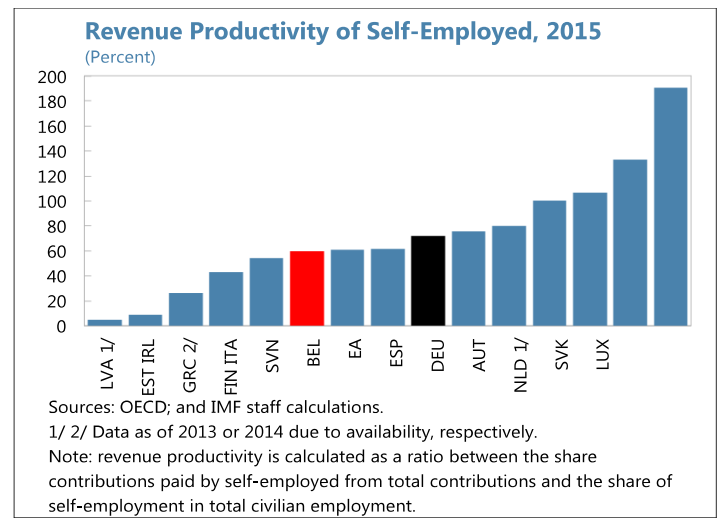

The tax burden on pensions is favorable to retirees. According to the OECD (2015), both the gross and net replacement rates in Italy are on average about $17 \%$

\footnotetext{
${ }^{12}$ For contributions rates of $11 \%$ for employees and $22 \%$ for employers, the "neutral" rate for selfemployed is approximately $(0.11+0.22) /(1+0.22) \approx 0.27$.
} 
points higher than for the OECD average retiree. The extension of the non-taxable area for retirees, as was the case in the 2017 budget, will further widen the gap. Compared to wage earners, retirees in Italy are subject to preferential tax treatment in terms of a higher tax-free allowance and full exemption on health contributions on pensions. Compared to retirees in other OECD countries, Italy offers tax relief on pension income from private schemes.

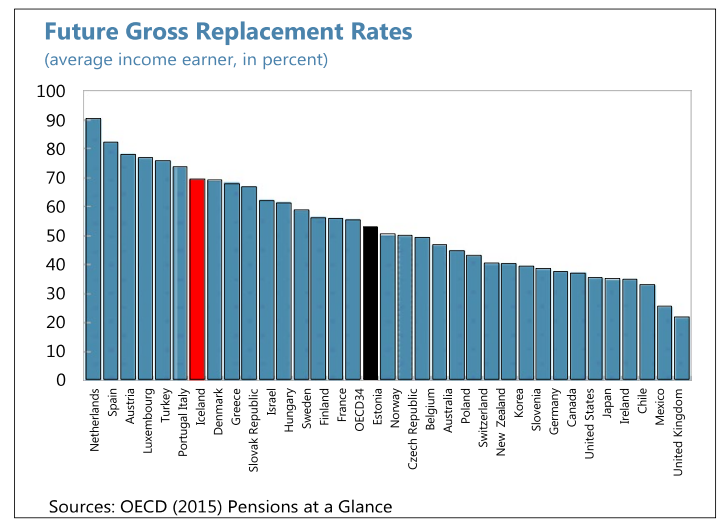

Deviations from general rules and partial reform reversals can also undermine past reforms. For example, the provisions in the 2017 budget for an annual fourteenth pension payment to low-income persons and higher tax-free thresholds for pensioners are costly and depart from actuarial fairness. ${ }^{13}$ Moreover, in January 2019 , early retirement rules were eased notably.

Workers who are at least 62 years of age with a minimum 38 years of contributions have become eligible for early retirement. Women who are at least 59 years of age with a minimum 35 years of contributions are also eligible. Moreover, automatic adjustments of the statutory retirement age to life expectancy were canceled for 2019-20. Such a reversal of past pension reforms would raise the number of pensioners, lower labor force participation and potential growth, and add to an already high pension bill.

Although the NDC in the long run is expected to reduce pension spending, by itself it is not enough to deal with Italy's fiscal problems. According to OECD (2015a, b), future gross replacement rates in Italy would remain one of the highest in the OECD (text chart) with both gross and the net replacement rates about 15-20\% points above the OECD average, depending on the average pensionable wage. Similarly, European Commission (2015) projects Italy's pension spending to remain more than 3\% of GDP above the average of other European countries. This is partly due to many features described above, including high discount factor, survivor pensions, and transformation coefficient for women with children, but also due to the

\footnotetext{
${ }^{13}$ Additional welfare benefits to retirees, as well as the fourteenth pension, are badly targeted as retirees have a lower incidence of poverty than the working age youth or the unemployed. Providing welfare benefits through, for instance, a national and universal anti-poverty scheme would better target those in need.
} 
very high pension contribution rate of 33\%. Rapid aging will also put strong pressure on spending on health and long-term care that, according to European Commission (2015), is expected to increase by about 11/2\% of GDP by 2060 (net of lower spending on education).

\section{Long-run simulations}

In the latest report by the Department of the State Accountant General (RGA) of the Ministry of Economy and Finance, long-term pension spending is projected to remain subdued, supported by the implementation of the above-mentioned past pension reforms and strong recovery in employment and productivity. According to the RGA (2017) projections, pension spending as a ratio of GDP is expected to increase from $15.7 \%$ in 2015 to just above $16 \%$ in 2045 and decline afterwards, reaching $13.1 \%$ by 2070 . Based on these findings, the pension system and overall public debt are understood to be sustainable over the long term, and it is argued that Italy is in much better stead than many other euro area members that have still to come to terms with age-related spending.

There are several offsetting factors that contribute to these projections. Firstly, the RGA notes that adverse demographic trends as captured by rising old-age dependency are the main drivers of future pension increases, adding about $11 \frac{1}{2} \%$ of GDP to pension spending by 2050 . Secondly, over the next decade, until 2025 , the benefit rate-the ratio of average pensions to GDP per worker-is expected to increase pension spending, owing to the generosity of the old though declining DB component compared to low productivity growth. Thereafter, the share of retirees under the NDC scheme is projected to become sufficiently large to dominate the more generous older DB scheme, settling the benefit rate on a modest downward trend. Thirdly, the strongest savings in the RGA's projections stem from a sizeable pick-up in the employment rate, with a notable increase in labor force participation and a substantial decrease in unemployment, as well as from reforms to restrict early retirement and extend retirement ages (eligibility rate)_reducing pension spending by about $2 \frac{1}{2}$ and $6 \%$ of GDP over the long-run, respectively. With the unemployment rate reaching as low as $5.5 \%$ of GDP by 2050 (and remaining steady afterwards), Italy is expected to move from one of the worst to among the best performers in the labor market.

Relaxing some of the optimistic demographic and macroeconomic assumptions suggest spending would be notably higher (Fig. 3).

The simulation results indicate that for the RGA (2017) projections to materialize, the NDC system must cut average pensions of future retirees further by about $2 \frac{1}{2} \%$ of GDP (or by more than by $20 \%$ ). The increase in the employment rate for the 15-64 age bracket in RGA (2017) appears optimistic, based on current policy settings. It increased from $56 \%$ in 2015 to $661 / 2 \%$ in 2070 , driven largely by a decline in the unemployment rate to about $5.5 \%$ by $2070 .{ }^{14}$ However, Italy's long-run average unemployment rate has been around $91 / 2 \%$. Assuming Italy's unemployment rate

${ }^{14}$ Note that employment levels are also assumed to be higher owing to an increase in the labor force. 

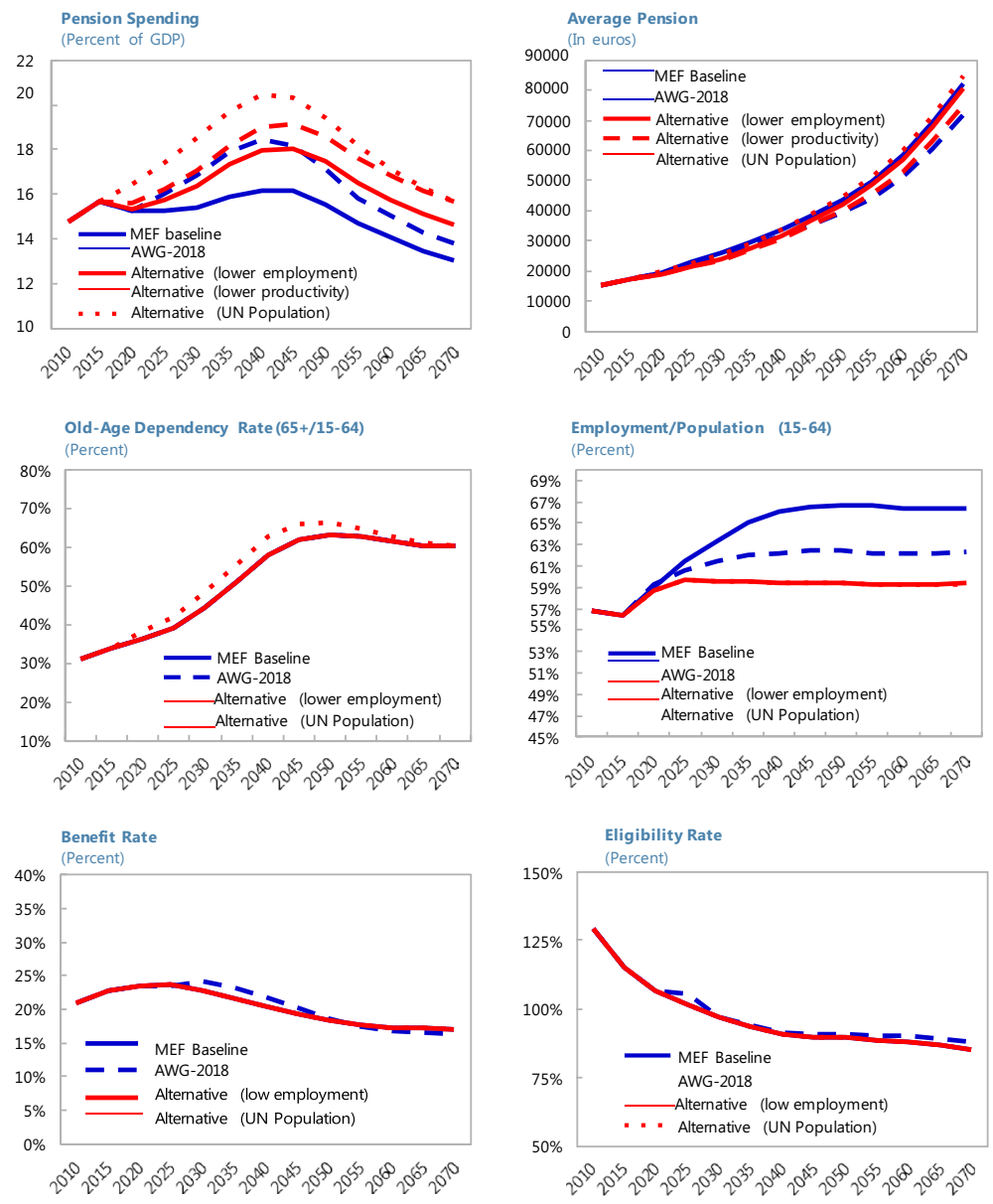

Sources: 2018 Aging Report, Ministry of Economy and Finance; UN, and IMF staff calculations.

Notes: The alternative scenarios use IMF staff's employment projections, assumes permanetly lower labor productivity (by about $1 / 2$ percent per year), and uses the UN's 2017 population projections. The blue dash lines use 2018 AWGassumptions.

Fig. 3 Italy: Pension Simulations Under the RGA, AWG, and Alternative Projections Sources: 2018 Aging Report, Ministry of Economy and Finance; UN, and IMF staff calculations. The alternative scenarios use IMF staff's employment projections, assumes permanetly lower labor productivity (by about $1 / 2 \%$ per year), and uses the UN's 2017 population projections. The blue dash lines use 2018 AWG assumptions

settles at $9 \%$, which implies an increase in the employment rate to about $60 \%$ in the long-term, the total pension spending increases by $1 \frac{1}{2} \%$ of GDP by 2070 (solid red lines in Fig. 3).

With strong employment recovery, the authorities are also expecting per capita real GDP and real labor productivity to grow at around $13 \% 4 \%$ annually, far above what has been observed for the last few decades. Such projections appear very optimistic. Lower TFP growth would lower GDP growth immediately but would 
impact pension benefits slowly-through wages that pass through to lower contributions and thus lower notional stock of pension capital. According to the RGA (2016), $0.25 \%$ points lower labor productivity growth would lead to about $0.5 \%$ of GDP higher pension spending in both 2040 and 2060, whereas $0.2 \%$ points lower TFP alone would increase the pension spending to GDP ratio by $0.6-0.7 \%$ of GDP, respectively. In response to a permanent negative labor productivity shock (of about $1 / 2 \%$ points per year), our simulations suggest that pension spending would be about $1 \%$ of GDP higher in both 2040 and 2060 (red long dash lines in Fig. 3). ${ }^{15}$

The 2017 population projections by the United Nations Population Division point to more rapid aging in Italy compared to demographic projections with base year 2016 recently published by ISTAT, increasing the long-run pension spending further by about $1 \%$ of GDP at peak (red dotted lines in Fig. 3). The RGA (2017) also reports an additional set of pension projections based on the EC-EPC (AWG) 2018 assumptions (with a steady state unemployment rate of about $7 \frac{1}{2} \%$ as well as a faster achievement of $1 \%$ TFP growth by 2035). The result is an increase in pension spending by about $2 \%$ of GDP at peak (blue long dash lines in Fig. 3) when compared to the national scenario.

In sum, taking more prudent assumptions for the employment rate, productivity growth, and demographics, which are closer to the historical record and based on current policy settings, pension spending as a percent of GDP is projected to reach 20.3 in 2045 (about 4\% of GDP above the RGA's baseline projection for 2045) before decline to 15.7 in 2070 (about $2 \frac{1}{2} \%$ of GDP higher than RGA's baseline projection for 2070).

\section{Reform options}

Consideration should be given to enacting measures that would yield savings in the near term and secure savings over the medium term, consistent with current policy settings. ${ }^{16}$ Near-term savings come from addressing the excessive generosity and lack of actuarial fairness in the DB and mixed schemes, and several options to

\footnotetext{
${ }^{15}$ A temporary negative labor productivity shock of the same size (over the period 2016-25) though would result in a $0.4 \%$ of GDP higher pension spending between 2025 and 2040 before the impact of the shock fades away.

${ }^{16}$ Cross-country as well as Italian experience suggest that pension reforms may face political opposition (e.g., France) or sometimes can run into institutional and legal boundaries, often manifested in constitutional principles such as equality and proportionality. An example is whether pension measures should apply to new retirees (i.e., on a flow basis) or to existing pensioners (i.e., impacting the stock). In some institutional settings pension measures can often be best implemented in a context of a coherent systemwide reform rather than in a piecemeal or ad hoc manner, affecting only certain categories of pensioners. It can also be easier-both from institutional and political perspectives - to implement pension reforms if they are based on well-established system-wide principles such as equalization of internal rates of return or actuarial fairness. For example, Kohli and Arza (2011) argue that reforms that involve stronger link between contributions and benefits may be more legitimate and easier to implement since, when compared to retrenchments or stand-alone parametric changes, these appeal to shared values and norms. Pension reforms should also be clearly justified and accompanied by socio-economic and legal assessments. Every effort should be done to clarify reform needs, that, inter alia, can involve improving system-wide equity or overall fiscal sustainability.
} 
this end are outlined below. These could go toward creating the room for achieving higher primary surpluses that Italy needs to put public debt on a firm downward trajectory as well as to improve intra-generational equity by shifting the adjustment on retirees who thus far have been relatively better off. Longer-term savings come from using more realistic (or conservative parameters) that guide long-term pension benefit calculations as well as ensuring actuarial balance.

Our results show that there is merit in: (1) eliminating the fourteenth pension payment fully and the thirteenth payment with an equivalent reduction in annual benefits for all retirees in the DB and mixed schemes. Support for the most vulnerable-a justification provided for the introduction of the fourteenth pension payment to low income retirees in the 2017 budget - could be achieved through the social safety net, in particular a well-designed guaranteed minimum income scheme; (2) introducing an age limit for a surviving spouse and limit any payments to relatives other than surviving spouse or orphan. This would restrict eligibility for a survivor pension, reduce spending, and incentivize labor force participation; (3) recalibrating existing pensions based on the steady-state NDC formula or equivalent parameters for accrual rates and/or pensionable earnings. This would serve to reduce short- to medium-run pension spending by reducing benefits to those who have benefited from the generous DB scheme. It will not affect the long-run steady-state spending (given by the NDC); (4) harmonizing (effective) contribution rates of self-employed with those of wage earners. Lower contribution rates for the self-employed constitutes preferential treatment.

Although from a system-wide point of view lower contribution rates in the NDC eventually translate into lower pension benefits, it reduces the financing available to the pension system in the PAYG system and is a source of unfairness.

Moreover, (5) an option for reducing the high labor tax wedge-as part of a fiscal devaluation strategy-while lowering long-run replacement rates can rest on lowering employers' pension contributions. This not only reduces the tax wedge on labor for current workers, but also translates into lower future pension spending via the NDC scheme.

However, this is not the first-best policy choice from the point of view of a fiscal devaluation when there is a tight (and actuarially fair) link between contributions and benefits that can be imposed by the NDC, since in that case pension contributions are effectively deferred savings that are less distortionary than other contributions (e.g., health) that are more redistributive in nature. This option could be considered if future pension spending cannot be reduced by other means. There is also value in: (6) subjecting pension benefits to health contributions and realign the tax-free threshold with wage earners. Retirees should not be burdened with pension or unemployment contributions, although they are relatively more frequent consumers of health services and therefore should pay health contributions. Consideration should also be given to reversing the higher tax-free threshold for retirees introduced in the 2017 budget; and (7) adjusting the NDC discount factor to reflect realistic growth potential and introduce an automatic adjustment mechanism that links pension spending to the long-term actuarial balance (as, for example, done in Sweden, Canada, and Germany). The main purpose of such a mechanism is to allow for automatic adjustments in current pension payments as a response to permanent shocks, thus helping to keep the pension system solvent without a possible need to increase payroll taxes (that in turn would lead to increases in future benefits). The discount 
factor currently fixed at $1.5 \%$ annually is well above the Italy's long-term growth potential based on current policy settings.

A key implication of the above simulations is that Italy needs to pursue comprehensive growth-enhancing reforms as a matter of urgency to reduce nominal wage rigidities and increase productivity and long-run employment rates. In the absence of such reforms that will take time to yield gains and reduce existing imbalances, even the self-adjusting NDC cannot ensure the sustainability of the pension system and public debt. It would, therefore, be prudent to set the safeguards as well as the system-wide parameters to be in line with the economy's potential under current policies rather than the stronger growth rates assumed in the RGA (2017) projections. Such an approach would reduce the risk of needing to take painful, large adjustments over a short time and thus reduce policy uncertainty.

\section{Revenue rebalancing: some considerations}

The Italian tax system has many aspects of a Dual Income Tax (DIT) regime. ${ }^{17}$ It applies a flat tax rate of $26 \%$ on capital income (dividends, interest income, and capital gains on securities), ${ }^{18}$ and $21 \%$ on rental income. Labor income is subject to a progressive scale with a starting rate on the first earned euro of $23 \%$ and a top tax rate of $43 \%$ for income exceeding $€ 75,000$ (the personal income tax is known as "IRPEF"). The corporate income tax (CIT) rate, the so-called "IRES," stands at $24 \%$, but a surcharge of $3.5 \%$ is imposed on financial and insurance companies. In addition to the IRES, there is a "regional production tax" - an origin-based valueadded tax known as the IRAP_-imposed as a fixed rate of $3.9 \%$ on the net value of production. ${ }^{19}$ However, tax rates remain high and are applied on a relatively narrow base. Total government revenues - at $43.5 \%$ of GDP - compare favorably with the EU average of $37 \%$ (Table 2). Out of this, total tax revenues of $29.7 \%$ of GDP in 2015 also compare favorably with revenues in the region.

About high tax rates, it should be noted that the labor tax wedge is high-e.g., for a single person earning an average income it is $47.9 \%$, well above the OECD average of $35.9 \% .^{20}$ This pattern is observed across levels of income and types of

\footnotetext{
17 The essence of a DIT regime is to tax capital at a low single rate and labor income under a progressive schedule.

${ }^{18}$ The $26 \%$ flat rate applies in the case of non-qualified shareholding. If certain thresholds' requirements are met, then $49.72 \%$ of the (qualified shareholding) capital gains or dividends are subject to the progressive personal income tax scale. A reduced rate of $12.5 \%$ is applied to the share of capital income deriving from State securities; and a Tobin tax exists on financial transactions and stamp duties, consisting of taxes on stock of financial assets rather than incomes.

19 Ten percent of the IRAP paid during a year can be deducted from the IRES. The labor cost for openended employees can be deducted from the IRAP tax base; there is a possibility for regions to reduce up to zero the tax rate of $3.9 \%$ or increase it by up to $0.9 \mathrm{pp}$.

${ }^{20}$ The tax wedge is sum of taxes and SSCs paid by employees and SSCs paid by employers, minus family received benefits. The average tax wedge is the tax wedge divided by the total cost of labor for the employer. This measure can be computed at various levels of income and types of households (singles, couples, with or without children). The authorities plan to reduce the labor tax wedge by $0.2-0.3 \%$ of GDP in 2020-21. This is to be implemented by extending the national income tax bonus (from $€ 80$ per month to $€ 100$ per month) in 2020 and potentially folded into a planned tax reform in 2021.
} 
households. ${ }^{21}$ The ratio of the social security contributions (SSC) to GDP is $13.4 \%$, which is $2 \%$ points higher than the EU average. The share of personal income tax (PIT) in total taxes is among the highest in the EU at $41 \%$. The CIT to GDP ratio is about $2 \%$, well below the EU average of $2.7 \%$, even though the CIT rate is significantly higher than the current EU simple CIT average (excluding Italy) of $21.3 \%$.

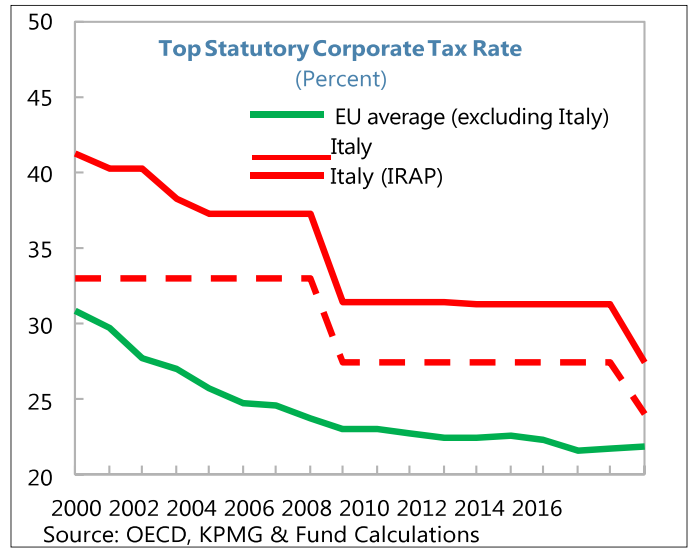

With the IRAP, Italian companies are taxed at an even higher rate. The standard VAT rate is $22 \%$ compared to an EU average standard VAT rate of about $21.5 \%$.

About the relatively narrow base, it should be noted that tax expenditures are quite large, estimated by Tyson (2014) at $6.5 \%$ of GDP, and by the "Commissione Mare" report on tax expenditures at 5.5\% of GDP. A recent report from the Ministry of Economy and Finance (MEF) identifies 600 measures of this kind on a legal basis. Italy has one of the weakest performing VAT systems in the EU, reflecting the presence of policy as well as compliance gaps. The VAT C-efficiency-an indicator of the departure of the VAT from a perfectly enforced tax levied at a uniform rate on all consumption - at about $40 \%$ is well below the EU average. ${ }^{22}$ Combining this with a compliance gap of about $26 \%$, as estimated by EC to be the fifth highest in EU, implies a policy gap of about $54 \%$ (the second highest in EU). ${ }^{23}$ Moreover, the CIT revenue productivity is only $7.4 \%$ compared to the EU average of $13.4 \%$. Alternatively, the Implicit Tax Rate on Corporate Income in Italy was 25.9\% in 2012 (the latest year available), as compared to $17.8 \%$ for Spain and $20.8 \%$ for the UK. Finally, tax evasion is very high. On average and over the period 2012-2014, the amount of

\footnotetext{
21 To reduce the labor tax wedge, Italy has adopted several measures, including SSC exemptions, the $€ 80$ PIT reduction, and deduction from the IRAP tax base of the labor cost of hires with permanent contracts.

22 See Keen (2013) for a detailed discussion of the C-efficiency measure.

23 The policy gap can be further decomposed into those arising from exceptions and rate dispersion.
} 


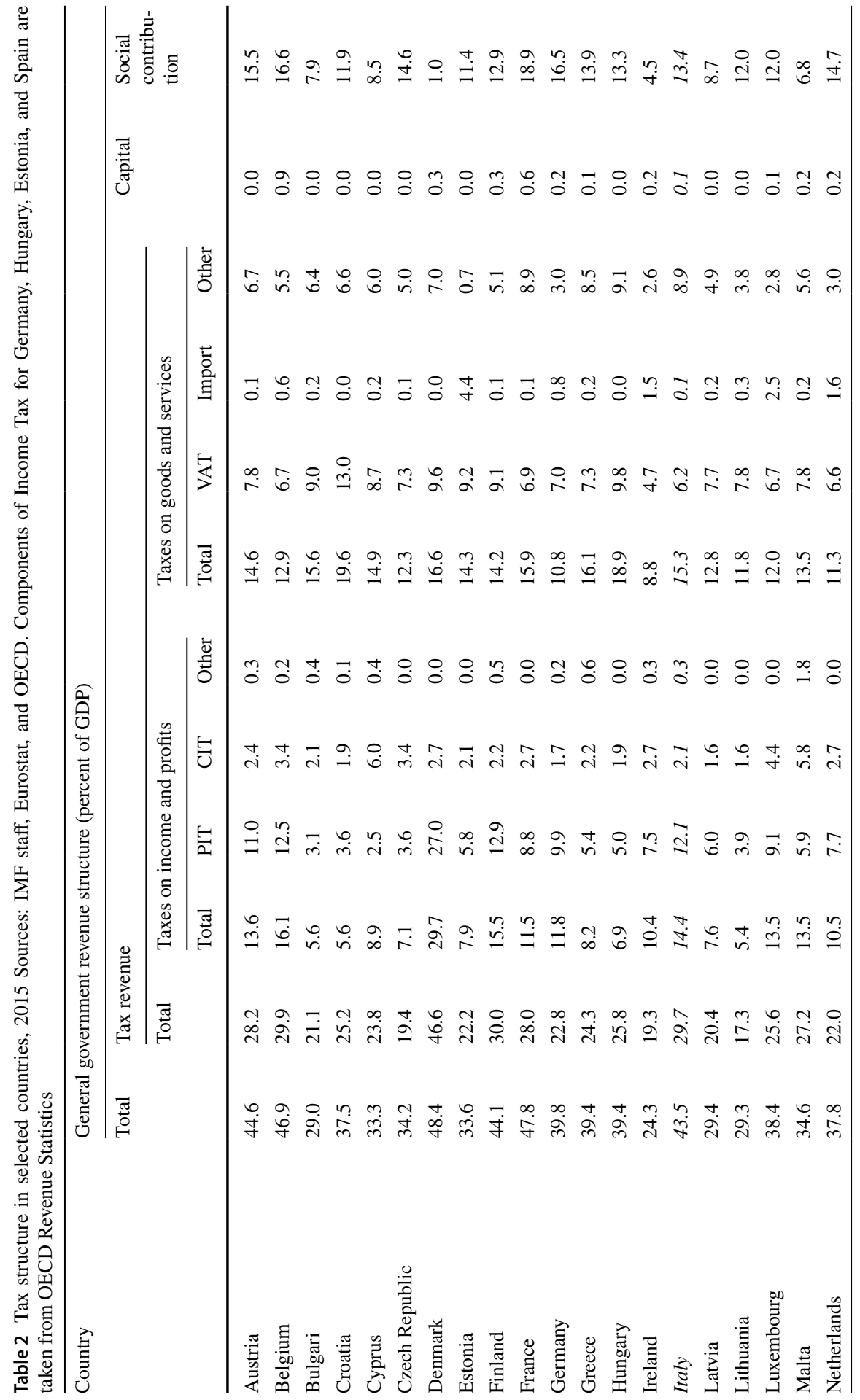




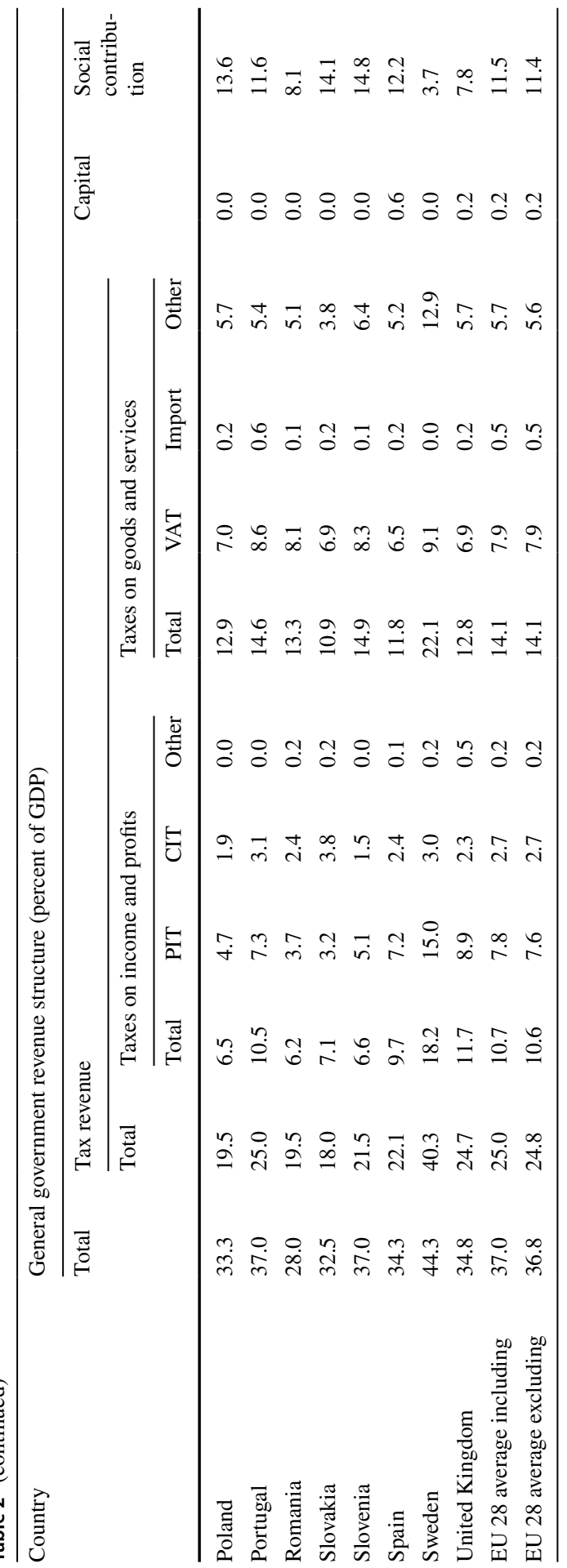


revenues forgone per year is estimated by the Ministry of Economy and Finance at around $€ 110$ billion. The stock of unpaid tax and SSC debt in 2016 was $€ 614$ billion.

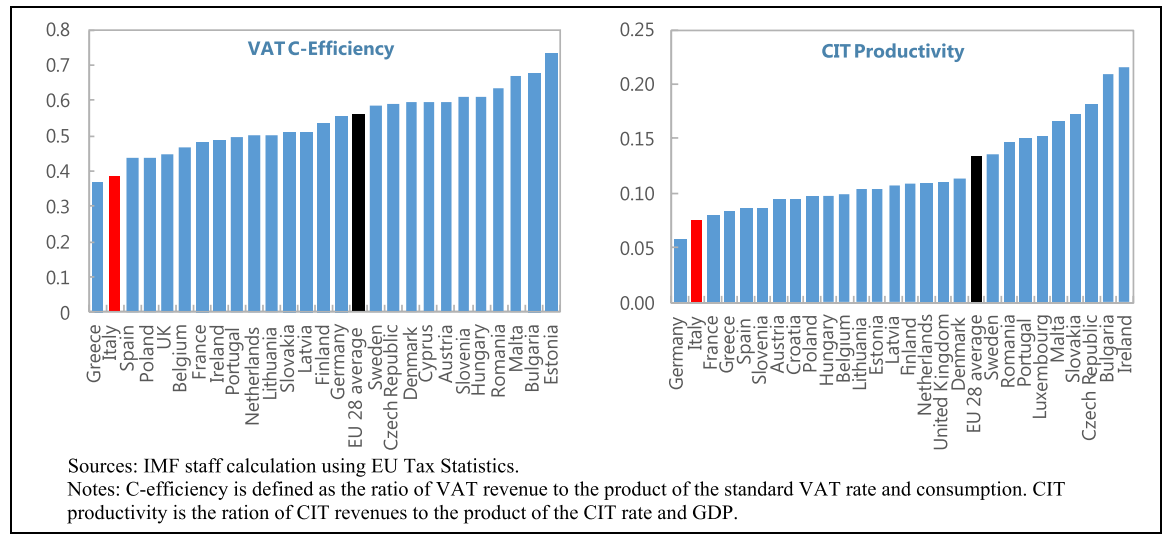

A "fiscal devaluation" (see De Mooij and Keen 2012), support for investment, and a tax administration reform would make for a growth-friendly strategy. Specifically, shifting the tax burden from labor income to less distortive tax bases would include (a) lowering employers' SSC rate to closer to the EU average; (b) using well-designed targeted instruments to increase labor supply; (c) introducing a modern property tax on primary residences and updating cadastral values; and lowering the VAT policy and compliance gaps, e.g., by harmonizing the reduced VAT rates, reducing the range of items subjected to reduced rates or exemptions, and considering a moderate increase in the standard VAT rate; (d) eliminating inefficient tax expenditures (e.g., abolishing the mortgage interest tax credit); and (e) strengthening capital gains taxation by ensuring Italy's right in the domestic law to tax capital gains from offshore indirect transfers of assets.

Investment could be encouraged through more effective, efficient, and credible tax provisions, building on measures such as adoption of an Allowance for Corporate Equity (ACE) regime since $2012^{24}$ and several internationally-required anti-taxavoidance provisions. ${ }^{25}$ Specifically, this strategy would include (a) streamlining targeted tax incentives to encourage innovation and R\&D investment; (b) improving the design of ACE, e.g., by providing a higher ACE rate for start-ups; (c) abolishing the intellectual property (IP) box regime; and (d) improving the overall investment climate by addressing uncertainty in tax matters that dampen taxpayers' confidence and investment, e.g., by making the R\&D tax credit permanent and credibly announcing the non-extension of enhanced depreciation.

\footnotetext{
24 The ACE rate was reduced from $4.5 \%$ to $2.3 \%$ in 2017 and $2.7 \%$ in 2018.

25 Examples include rules to limit interest deduction for the CIT (an earning-stripping rule) and rules to limit profit shifting through Italian-controlled companies located in low tax ("black-listed") jurisdictions (controlled foreign company rules).
} 
Reforming tax administration, includes restoring autonomy to fiscal agencies, strengthening enforcement, relaxing legal constraints to tackle tax debt, and bringing instalment arrangements in line with international best practice.

\section{Fiscal rebalancing/devaluation}

A "fiscal devaluation" is a revenue-neutral shift in the tax structure (e.g., from employers' social security contributions toward value-added and property taxes) with positive effects on output. Reducing employers' SSCs can stimulate labor demand in the short term. Given wage rigidities and being in a monetary union with major trading partners, cutting employers' SSCs can reduce labor costs (and producer prices, including those of exports) as well as increase labor demand in the short term. The resulting favorable effect on the trade balance could be temporary though, if nominal wages eventually adjust to fully offset the cut.

However, the impact on employment and output may be longer lasting with a shift in the tax burden toward non-labor income (VAT and property taxes) that is also less distortionary.

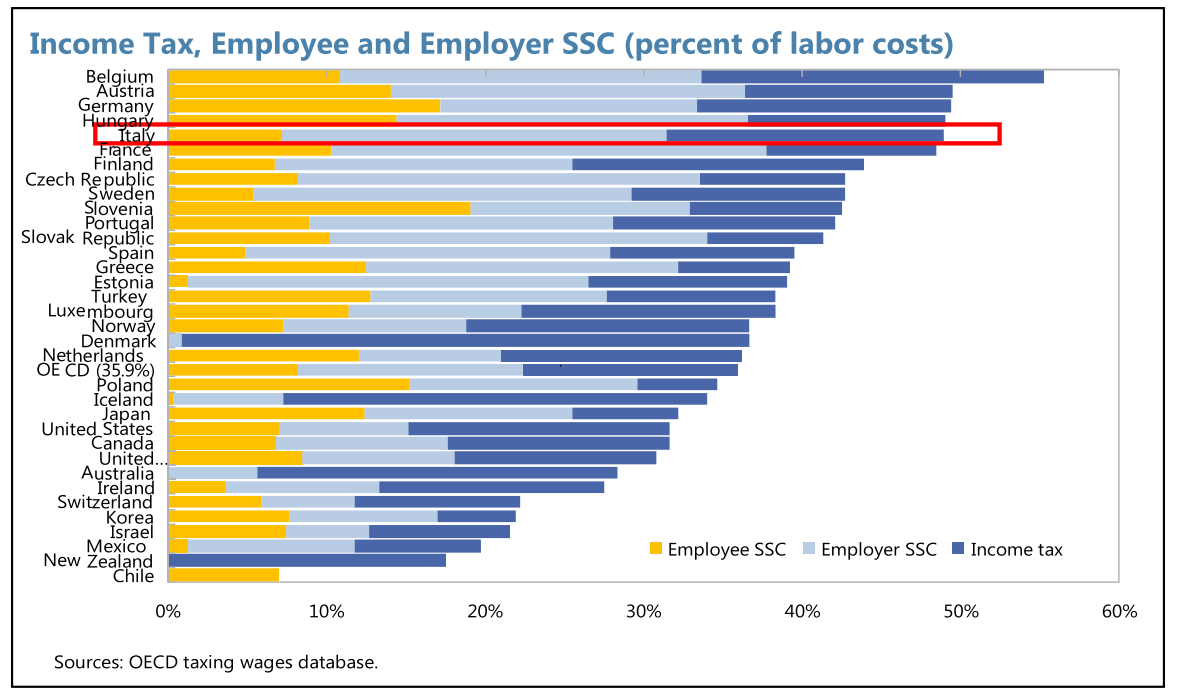

Moderately increasing the share of employees' SSCs in total could, under certain conditions, partially finance the cut in the employers' SSC and ensure a stable stream of funding.

Changing the composition of the SSCs by adjusting the employees' SSC share would address the risk of using general revenues to finance pension and social security obligations. 
However, there could be a negative effect on wages and labor supply, and thus the measure could best be introduced should the government decide to reduce personal income taxes and be complemented with other targeted measures.

Better use of targeted measures toward increasing labor supply, especially of low-income earners, is recommended. Italy has the lowest labor supply of married women among EU countries. This is in part driven by a tax credit for non-working spouses that discourages their labor supply. A better design is to replace this with a tax credit if both spouses are employed (called working family, or in-work, tax credit), which can be increasing with the number of children (as, e.g., in the UK and the US). Available evidence suggests that adopting in-work tax credits for low income earners, within a revenue-neutral reform, can have sizable impacts on the female labor-force participation and aggregate employment (Saez et al. 2002; De Mooij 2008). For Italy, Colonna and Marcassa (2015) find that replacing the dependent-spouse tax credit with an in-work tax credit increases married women participation rate by $3 \%$ points. However, although in-work tax credit alleviates the tax burden at the extensive margin, there is a risk of increasing distortion at the intensive margin of labor supply, which can be mitigated through an appropriate design of the in-work credit.

Re-introduction of a property tax on primary residences is a vital element of a modern tax system in Italy. The municipality property tax (known as "IMU") and the municipality tax on local services ("TASI") for primary residences were abolished in 2015 , owing to their unpopularity. ${ }^{26}$ The property tax is an efficient instrument and can raise significant revenues. In 2015, recurrent taxes on immovable property raised $1.6 \%$ of GDP in Italy. Even if taxes on primary residence were reintroduced, to fully exploit the potential of the property tax, it is essential to reform the cadastral system and update the cadastral declared value of the property on the Rogito (deed of sale). Using municipal property taxes to finance local governments enables the central government to reduce transfers to local governments and free up resources to fund the lowering of employers' SSCs.

Lowering the VAT policy gap by harmonizing the reduced VAT rates can raise significant revenues. The VAT compliance gap as of 2015 was $€ 35.1$ billion, about $26 \%$ of total VAT liability (2.1\% of GDP), significantly higher than the EU-27 average $(12.8 \%)$. Halving this gap, while maintaining all tax rates unchanged, would increase revenues by $1.05 \%$ of GDP. Moreover, based on EU (2016), fully closing the policy gap, i.e., if no VAT reduced rates and exemptions were applied, would enable Italy to increase its VAT revenue by an additional $15 \%$. This estimate, however, is based on a full compliance scenario. Adopting a lower number of reduced rates could be an intermediate step toward lowering this policy gap. Decreasing the range of items subjected to reduced rates or exemptions is also important for lowering the policy gap. For instance, instead of exempting taxi services from the VAT,

\footnotetext{
26 The IMU on luxury houses remains enacted, but the tax was reduced. The basic rate for the IMU for the primary residence was equal to $0.76 \%$, but it varies depending on the location of the house by a maximum of $+0.3 \%$.
} 
they can be subject to the reduced rate; however, if taxis pay VAT on their inputs, a careful analysis is needed to assess the revenue impact. ${ }^{27}$

Tax arrears are at an alarmingly high level reaching €614 billion (as of 2016). Toro et al. (2015) suggest that a significant amount of arrears is not collectable (e.g., because $31 \%$ of debtors are out of business or bankrupt and $36 \%$ relate to cases where enforcement actions were taken but did not result in actual collection) calling for effective write-off arrangements. Recurrent tax concessions undermine voluntary compliance culture and the effectiveness of tax administration. About $€ 31$ billion of tax arrears is deemed recoverable. Enforcement actions are critical that could be supported with timely filing, modern payment arrangements, and relaxing legal constraints.

Italy embraces a large set of tax credits in part reflecting income redistribution mechanisms. For example, within the personal income tax, there are tax credits for income sources, an $€ 80$ per month bonus, and family tax credits (including for dependent spouses and children).

Other allowances/deductions within the tax structure include substitute tax on capital income, ACE allowances and participation exemption, reduced VAT rates and compulsory payroll tax deductions. The largest item is the tax credits for income source. This item reflects the fact that the first bracket of income (from zero to $€ 15,000)$ is subject to a tax rate of $23 \%$.

These tax credits are reduced progressively until, at income levels above $€ 55,000$, they no longer apply. Thus, this tax credit is warranted for redistribution.

However, some other tax expenditures within the direct income tax should be revisited and could be gradually eliminated, including: (1) mortgage interest tax credit. The tax credit is equal to $19 \%$ of the mortgage interest payments. The upper limit of this tax credit is $€ 4000$. Since capital gains on primary residence in Italy are exempt from the capital gains tax, and high household debt could be associated with stability risks (IMF 2016a), the mortgage interest tax credit should be phased out or at the very least its generosity should be lowered; and (2) tax credit for medical expenses. This tax credit is equal to $19 \%$ of medical expenses exceeding $€ 129.11$. $^{28}$ Yet, redistribution motives in this area can be better-targeted using government expenditures, and furthermore, currently, health services are either subject to a reduced VAT rate or exempted from the VAT in Italy.

\section{Supporting investment}

A simple and certain business taxation strategy is recommended that relies on two key elements: (1) innovation and allowance for corporate equity, and (2) removal of inefficient incentives. Note that in the presence of ACE, changes to statutory CIT

\footnotetext{
${ }^{27}$ Several measures were introduced in recent years to reduce the VAT gap. Examples include optional electronic invoicing, more frequent VAT invoice transmissions, and split-payment and reverse-charge mechanisms.

${ }^{28}$ A 2015 analysis of the tax credit for medical expenses based on tax returns statistics show that the beneficiaries, mostly with incomes below $€ 55,000$, are 17.3 million for a total amount of $€ 16.2$ billion of expenses.
} 
rates are less likely to impact investment decisions. The extent to which the revenue loss of the recent CIT rate cut from 27.5 to $24 \%$ can be compensated by increased investment and growth depends on profit shifting and location choice. The lower CIT rate can reduce incentives for profit shifting. However, this aspect is unlikely to be significant because, Italy has agreed to comply with the ATAD and the G20/ BEPS minimum standards. These anti-avoidance measures help safeguard against profit shifting. The neutrality of the CIT regarding ACE means that any impact on investment will come in effect from changed location by multinational companies, but the location decision depends on several other tax and non-tax factors (including labor regulations and labor supply). Firms that would have invested anyway would also benefit from the rate cut, adding to the fiscal cost but without benefit.

ACE contributes to very low, perhaps even negative, marginal effective tax rates, thereby positively impacting investment. Effective tax rates summarize the impact of major elements of the tax base, such as depreciation allowances and the ACE, along with the rate of tax itself. In theory, the marginal effective tax rate (METR) a measure of the tax burden on an investment that just yields the required rate of viable return-is zero in Italy because the ACE does not tax normal return. ${ }^{29}$ In the text Figure, taken from the Oxford Center for Business Taxation, the METR is negative, suggesting that the marginal investment receives a subsidy in Italy (although these calculations must be interpreted with caution as the negative rate is driven by strong assumptions underlying the calculations). Another measure is the effective average tax rate (EATR), which is important for multinational companies' location choice for new affiliates (it measures the proportion of the present value of pre-tax profit that would be taken in tax). The EATR in Italy compares favorably to several EU member states including Spain, France, Germany, and Portugal.

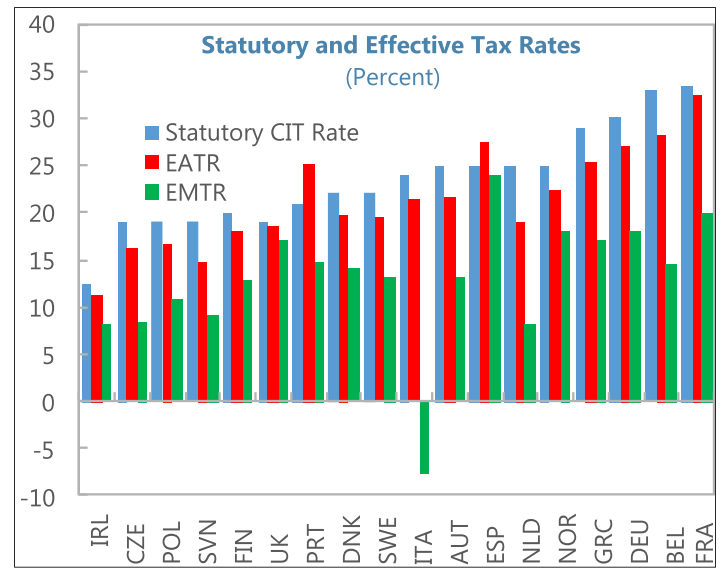

\footnotetext{
29 The METR considers the size of allowances and deductions in determining taxable profit and measures the proportionate increase in the required rate of return on an investment project.
} 
The impact of the ACE on investment could be enhanced, for instance, by providing a higher ACE rate for small businesses (perhaps contingent on an age requirement), re-linking the rate to government bond yields, and a premium to reflect risks, and introducing a minimum rate of $2-3 \%$ in line with the EU Common Consolidated Corporate Tax Base (CCCTB) proposal to enhance tax certainty. ${ }^{30}$

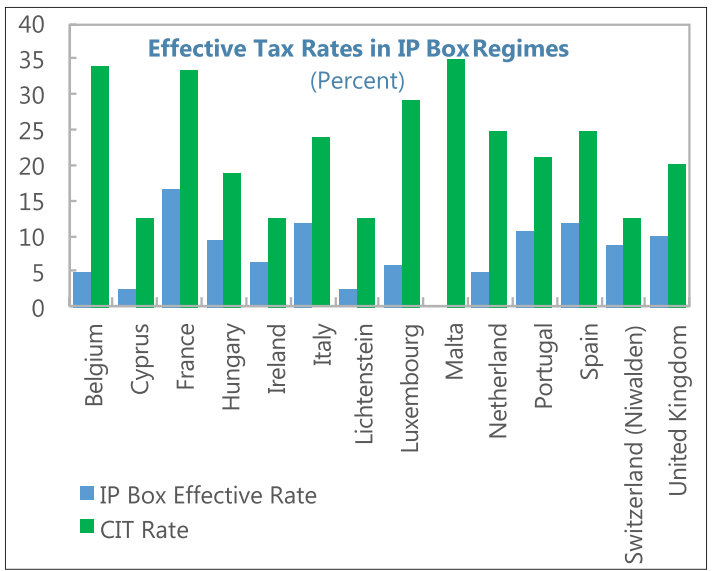

Well-designed R\&D tax incentives can have a sizable impact on productivity. Taxation can incentivize private $R \& D$ activities through the input side-in the form of an R\&D tax credit or deduction-or the output side in the form of a reduced tax rate on IP income ("IP box").

While Italy has measures on both sides, the former measures are more efficient. ${ }^{31}$ Empirical evidence suggests that one euro spent by the government on R\&D tax incentives, on average, increases domestic private $R \& D$ by one euro, whereas one euro spent on an IP box can, at best, increase R\&D by less than one euro (IMF 2016b; Dumont 2015). Bloom et al. (2002) estimate that a $10 \%$ reduction in the cost of R\&D increases the level of R\&D by about $1 \%$ in the short run and $10 \%$ in the long run. Griffith et al. (2014) estimate that IP regimes have resulted in lower revenues from IP in the Benelux countries and the UK Not all EU countries adopt an IP box, while the tax rates for those that apply an IP regime are shown in the text figure. Italy exempts $50 \%$ of qualified IP income from taxation, and taxes the

\footnotetext{
${ }^{30}$ Within the 2017 supplementary budget, the base of the ACE tax deduction was changed from "the increase in equity since 2011 " to "the increase in equity in the last 5 years before the tax year considered".

${ }^{31}$ The strategy followed by Italy to scale-up investment and enhance productivity includes: (1) tax credits for R\&D investments; (2) accelerated depreciations, such as super and hyper-amortizations; (3) subsides to SMEs to repay loans and agreements with banks to promote access to credit, as envisaged by the so-called Nuova Sabatini Law; (4) specific credits and crowdfunding for start-up and SMEs; (5) tax allowances, such as ACE; (6) State guarantees on loans of SMEs; (7) a reduced tax rate on incomes from the direct use or license for IP incomes (the so-called Patent Box); and (8) targeted incentives to innovative start-ups.
} 
remaining $50 \%$ of that income at the statutory CIT rate of $24 \%$ implying an effective tax rate of about $12 \%$.

In general, there are some concerns with IP boxes. The IP tax relief: (1) rewards only success. Successful R\&D outputs are a function of many non-R\&D related inputs (including management) that are not characterized with market failure. IP regimes may discriminate against potentially important $R \& D$ activities that may not be successful quickly. (2) It is proportional to the amount of qualifying IP income, and not connected to the level of $R \& D$ expenditure. That is, two patents may generate the same income, thereby receiving the same benefits from the IP regime, even if they have different levels of $R \& D$ input. (3) It cannot perfectly target the location of $R \& D$. There is a distinction between the legal ownership of patents (and knowhow assets) and the location of R\&D activities that led to the patents. IP boxes can influence the location of the legal ownership of the know-how assets (within the multinational group) with little effect on domestic R\&D investments. Essentially, large enterprises particularly in the manufacturing sector benefit the most from this scheme.

Options to streamline the existing R\&D and investment incentives include: (1) abolishing the IP box regime. The October 2016 European CCCTB proposal envisages a super deduction for R\&D expenditures. If implemented, the CCCTB would phase out IP regimes. The 2017 supplementary budget attempts to harmonize the Patent box regime to OECD standards. (2) Making the tax credit for R\&D expenses permanent. (3) Credibly announcing that temporary super depreciation rules will not be renewed (starting from a given date). (4) Periodically assessing the effectiveness of the allowances for investment in innovative startups. Potentially, this measure should not be size-based and apply only to startups.

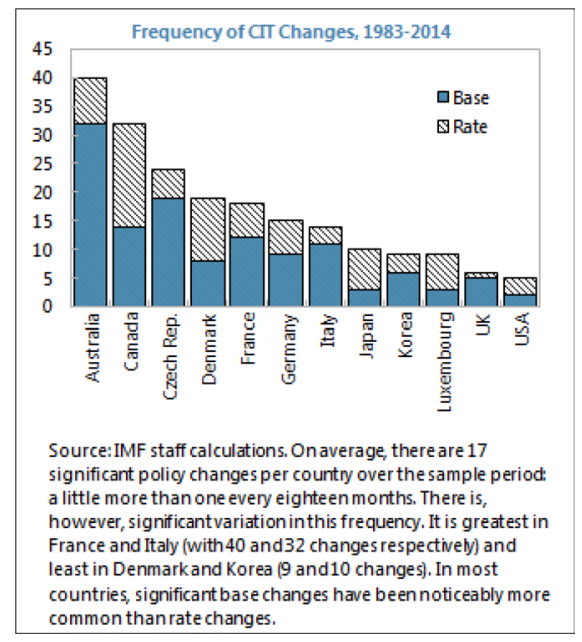

Frequent changes to tax policy and administration, and excessive use of temporary provisions can be an important source of uncertainty (IMF/OECD 2017). The 
frequency of tax changes in Italy is high compared to other G20 countries, and introducing or renewing temporary measures with varying conditions is prevalent. Temporary measures generate uncertainty when their expiry date is either unclear or not credible. Such uncertainty risks creating a hold-up problem, as firms defer investment until the uncertainty is resolved. ${ }^{32}$

\section{A growth-friendly fiscal policy mix}

The IMF's Global Integrated Monetary and Fiscal Model (GIMF) is used to illustrate the effects of the above-mentioned fiscal package. GIMF is a multi-country structural dynamic general equilibrium model featuring Italy, the rest of the euro area, and the rest of the world. It links the behavior of households, firms, and government sector within and among countries. The model has a consistent system of national accounting and stock-flow budget constraints for all sectors, including the government. The model belongs to exogenous-growth types of models, meaning that the long-term growth of output is exogenous. Hence, all fiscal or structural measures may change only the structure of the economy, possibly increasing permanently the level of real output per capita; never long-term growth.

The household sector consists of forward-looking optimizing households, as well as liquidity-constrained households who spend all their available income every period. The forward-looking households are modeled as overlapping generations (OLG) with finite lives, following the Blanchard-Weil-Yaari framework. The presence of OLG households breaks the Ricardian equivalence and is important for realistic results of fiscal policy in both the short and long run. Households gain utility from consumption and disutility from labor effort, they consume traded and nontraded services and goods, receive labor income, transfers from the government, dividends from corporations, and pay taxes-income, consumption, and lump-sum taxes. Firms produce intermediate and final goods using labor and capital inputs, accumulate capital, and import or export their production. Firms pay taxes from corporate income. Monetary policy in the euro area and rest of the world regions follows an inflation-forecast targeting rule to set policy interest rates. Italy is a member of the euro area.

Government collects tax revenues (consumption, labor income, capital income, and lump-sum taxes) and spends them on government consumption, investment, and transfers to households. Governments target specific debt-to-GDP (and thus deficitto-GDP) ratios and use a mix of instruments to achieve it. The government's commitment to sustainable public finance is credible for firms and households, who hold the stock of government bonds.

\footnotetext{
32 Gulen and Ion (2016) find evidence that policy uncertainty is persistently and negatively correlated with corporate investment, with an important part of the negative effect of tax-related uncertainty measured as the presence of temporary measures where the expiration date or the possibility for renewal are unclear.
} 
The scenario modeled assumes a permanent fiscal consolidation of about $1 / 2 \%$ of GDP (in the structural primary balance) per year for 4 years with the aim of achieving a small structural surplus in the medium term, supported by a pro-growth mix of revenue and expenditure reforms, and is compared to a trend or no-policy-change baseline. Two types of growth-friendly revenue and spending measures are considered along the envisaged fiscal consolidation path: shifting taxation from direct to indirect taxes, and lowering expenditure and shifting its composition from transfers to investment. On the revenue side, a lower labor tax wedge (1.5\% of GDP) is offset by higher VAT collections from reduced policy and compliance gaps (1\% of GDP) and introducing a modern property tax on primary residences ( $0.5 \%$ of GDP) ${ }^{33}$ On the expenditure side, spending on public consumption is lowered by $1.25 \%$ of GDP, while productive public investment spending is increased by $0.5 \%$ of GDP. The remaining portion of the fiscal consolidation, $1.25 \%$ of GDP, is implemented via reduced social transfers. In the model-based analysis, it is assumed that higher public investment spending and an associated higher level of government capital exert positive spillovers on private sector productivity. Finally, the marginal cost of borrowing, i.e., at issuance, is assumed to increase in the medium term from its 2018 average of $1.9 \%$. The 10-year Italian government bond spreads vis-à-vis German bunds are assumed to decline gradually from an average of 215 basis points in 2018 to 205 basis points in 2023, which is the average level of spreads over the past 10 years. Spreads are mainly driven by the evolving interest rate changes in Italy as German 10-year bund yields are expected to remain low over the medium term. Interest-rate spreads are expected to decline further in the long-term despite monetary policy normalization-given the quality of simulated fiscal adjustment and the GDP path in Italy.

\section{Italy-Germany 10-Year Bond Yield Spread}

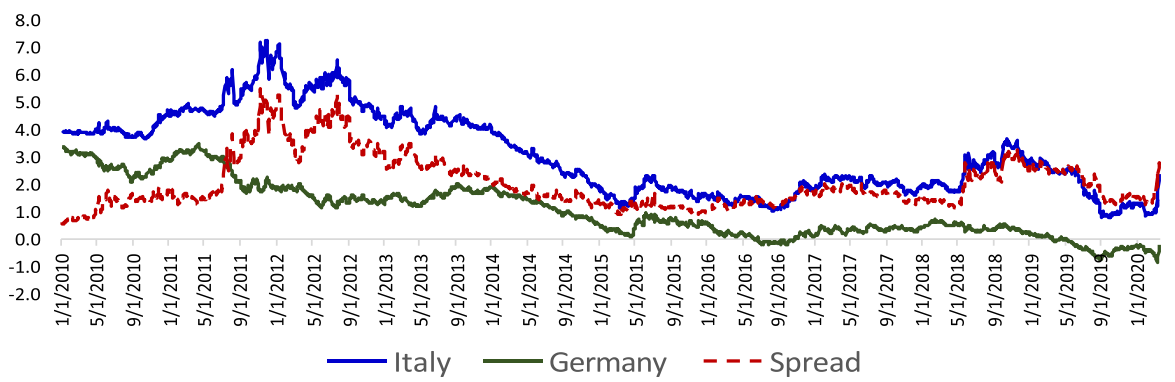

Source: Thomson ReutersDataStream

The policy package would result in an output increase of around $2 \%$ and a lower debt-to-GDP ratio of around $13 \%$ points in a decade (Fig. 4). The increase in output is even larger in the long run (around $2 \frac{1}{2} \%$ higher than the baseline) while the

33 The property tax is approximated by lump-sum taxes in the model-based analysis. 


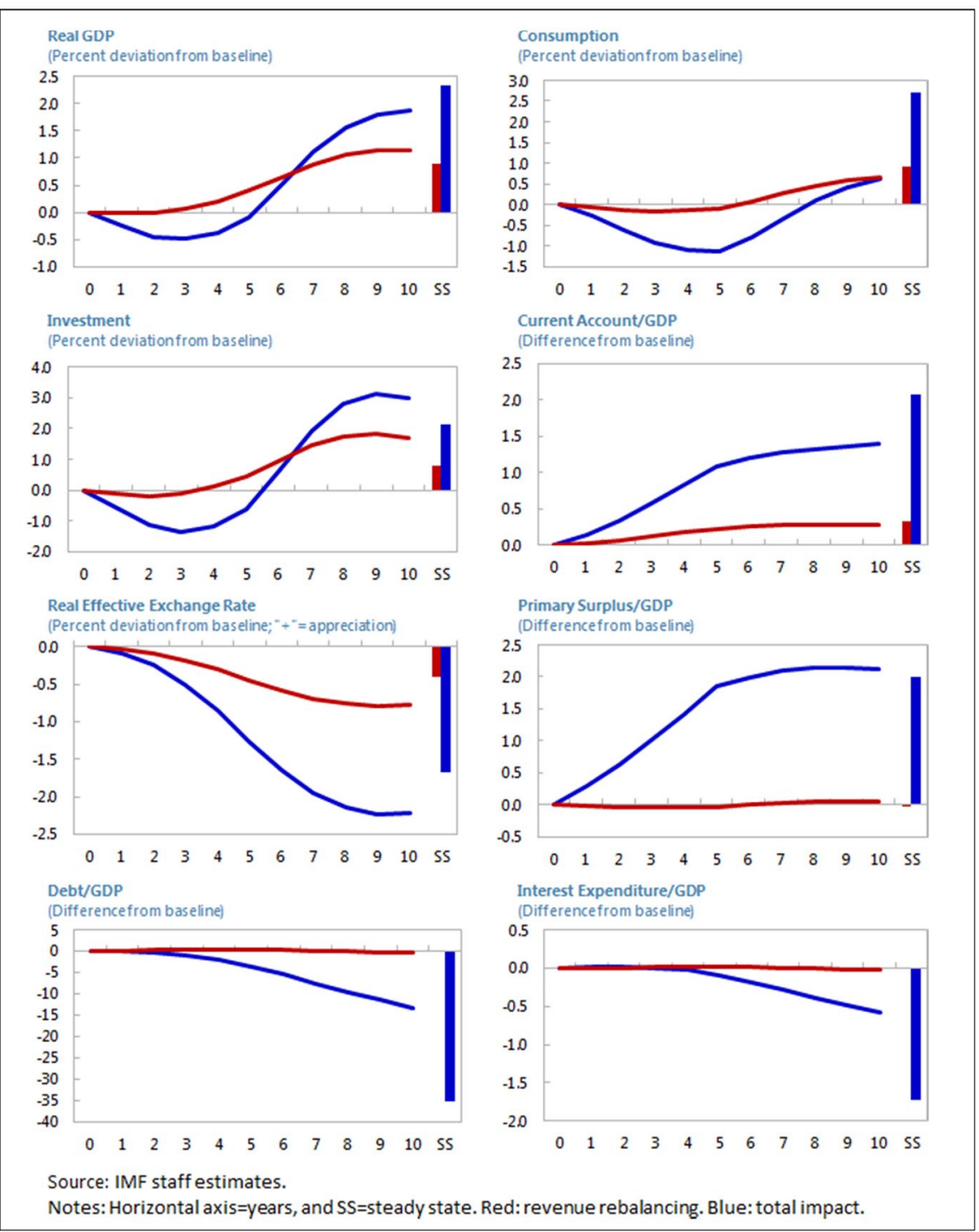

Fig. 4 Italy: simulated fiscal reform

debt-to-GDP ratio is more than $35 \%$ points lower than the baseline. For example, starting from $133 \%$ of GDP in 2018, debt-to-GDP ratio would decline to $98 \%$ in 10 years and GDP growth would be $0.2 \%$ points higher per year. The positive response of the economy is a result of a less distortionary new tax structure, with lower labor tax wedges, and of the more productive spending, namely on public investment, and lower debt-service costs (implementation of this package would bolster investor confidence). Lower taxes on capital induce firms to increase investment and raise their desired level for the private capital stock. Lower labor income 
taxes encourage households to provide more labor. The net effect of lower income taxes and higher lump-sum as well as value-added taxes is positive on private consumption in the long term. The revenue-neutral tax reform on its own-with no change in the debt-to-GDP ratio-would result in higher private consumption and output owing to the economy moving towards less distortionary sources of taxation.

The increase in productive public investment, lower public consumption and social transfers result in further output gains in the long run. The productive public spending stimulates private capital accumulation and the lower deficit and debt ratios result in significant savings on debt-service costs. In the short run, before the benefits of more productive investment and of lower debt fully materialize, the reduced social transfers and public consumption dampen somewhat private consumption and output. Short-term costs though are quite modest and are traded for significant longer-term benefits of permanently higher private consumption and output. The fiscal consolidation/composition shift scenario assumes that the measures are gradually phased in over the period of 4 years ( $1 / 2$ of GDP per year). If the announcement of the reform is fully understood by firms and households and fully believed, the short-term costs are even smaller than in the case when the general public considers permanent only the measures implemented in the given year and in the past, but do not believe that future reforms will be implemented. When households and firms believe the whole path of fiscal reforms they invest more from the outset and reap the long-term benefits of the fiscal consolidation sooner. Overall, the high quality of fiscal adjustment enhances the confidence about debt sustainability, hence, lowering the interest costs and offsetting the contractionary impact of a moderately-gradual fiscal tightening (see Blanchard and other 2019 on contractionary fiscal expansions in Italy). This contrasts with the Italian experience during the European debt crisis ${ }^{34}$ for three reasons: (1) the assumed adjustment in our simulations is more gradual; (2) the quality of fiscal adjustment is improved; (3) and fiscal multipliers are likely smaller because the output gap is narrower, and the public debt is higher.

\section{Conclusions}

This paper contributed to the fiscal policy discussions in Italy by: (1) assessing spending patterns from a long-term perspective to identify areas for savings; (2) evaluating the pension system; (3) analyzing the scope for revenue rebalancing; and (4) outlining a package of spending cuts and tax rebalancing that is growth friendly and inclusive. We showed that a comprehensive fiscal reform package predicated on a revenue-neutral and less distortionary tax reform, alongside current spending cuts and capital spending increases, can generate sizable output gains and a sustainably lower public debt ratio over the medium to long term. Short-term output costs of this fiscal package, if implemented credibly, are likely limited.

\footnotetext{
34 Italian government tightened its fiscal policy by over 3\% points of GDP in 2012 and subsequently output fell by almost $2 \%$ in 2013 .
} 
Acknowledgements We thank Romain Duval, Rishi Goyal, Zsoka Koczan, and Roberto Piazza as well as the Italian authorities for helpful discussions and comments. This paper was written before the Covid-19 pandemic. The views expressed here are those of the authors and do not necessarily represent the views of the IMF, its Executive Board, or IMF management.

\section{Annex: DB versus NDC pension schemes}

The Italian pension system is currently prorated over the defined benefit (DB) and notional defined contribution (NDC) schemes. As the names imply, a DB pension plan provides a specified payment amount in retirement, while an NDC plan allows employees and employers to contribute and invest funds over time to save for retirement. Key features of pure DB and NDC pension schemes are explained below:

\section{Defining the benefit}

The DB system rests on four key parameters: (1) the accrual rate $(a)$, that is the pension entitlement for a full year's coverage as a share of earnings; (2) a measure of earnings ( $w$ ) that usually is lifetime average earnings; (3) valorization factor $(u)$, that is, the way how the earnings of earlier years are adjusted to reflect changes in standards of living between the year of retirement and these earlier years; and (4) the retirement age $(T)$. The benefit is then defined as:

$$
D B=\sum^{T} w_{t}(\mathbf{1}+u)^{T-t} a .
$$

\section{Defining the notional contributions}

In the NDC system, each individual's contributions, (c), accumulate into a notional capital (in individualized accounts) that by end of any period $(T)$ is:

$$
K_{t, T}=\sum^{T} c w_{t}(1+\rho)^{T-t},
$$

where $\rho$ is the notional interest rate or the internal rate of return (IRR). In computing the annuity (a series of equal payments) at retirement, the accumulated capital stock is divided by the annuity factor $(\mathrm{G})$ that in turn is a function of life expectancy (LE) at retirement and the IRR:

$$
N A=\frac{K}{G[L E, \rho(L E)]}=\sum_{t=0}^{T} \frac{c w_{t}}{G[\ldots]}(1+\rho)^{T-t},
$$

The IRR in the pure NDC scheme is chosen to equalize the present value of system assets (A) with the present value of system liabilities $(L)$, or: 


$$
P V\left(L_{t}\right)=P V\left(A_{t}\right) .
$$

Total liabilities are the present value of the sum of workers accumulated capital (K) and pensioners' annuity (NA). Total assets are the present value of the stream of future contributions (plus technical reserves). In practice, this true IRR is only known ex post. However, it must be parameterized ex ante (to calculate the annuity) possibly based on the growth rate of the wage bill:

$$
\rho=n+g,
$$

where $n$ is the growth rate of labor force (population) and $g$ is the productivity growth.

\section{Steady-state equivalence}

It is clear from Eqs. (1) and (3) that the structure of the two systems is similar. When the rate of valorization in the DB and the internal rate of return in the NDC system are equal (i.e., $u=n$ ) and the accrual rate $(a)$ is equal the ratio of contribution rate to the annuity factor $(\mathrm{c} / \mathrm{G})$, the systems can, in fact, be identical. The main differences relate to the manner the schemes react to shocks and in available policy instruments to counter these shocks.

\section{Rules versus discretion}

In the NDC, pension benefits adjust automatically to shocks like a sudden decline in fertility (lower contributions) or an increase in life expectancy (that determines the annuity factor G). This is not to say that the DB system cannot cope with such shocks; this could be achieved by linking the formulae or retirement ages to life expectancy for example. Discretionary adjustments differ in terms of parameters that policy makers can control. Examples of these in the NDC are IRR computation rules, minimum retirement age, life expectancy tables, and methods to calculate annuity. In the DB scheme, many such parameters are absent or non-discretionary; instead, policy-makers can control, inter alia, accrual rates or the way pensionable earnings are calculated.

\section{References}

Akcigit, U., Baslandze, S., \& Lotti, F. (2018). Connecting to power: Political connections, innovation, and firm dynamics. NBER Working Papers 25136, National Bureau of Economic Research, Inc.

Anderson, D., Hunt, B., Kortelainen, M., Kumhof, M., Laxton, D., Muir, D., Mursula, S., \& Snudden, S. (2013) Getting to know GIMF: The simulation properties of the global integrated monetary and fiscal model. IMF Working Paper WP/13/55 (Washington: International Monetary Fund).

Anderson, G., \& Raissi, M. (2018). Corporate indebtedness and low productivity growth of Italian firms. IMF Working Paper WP/18/33 (Washington: International Monetary Fund). 
Andrle, M., Kangur, A., \& Raissi, M. (2018). Italy: quantifying the benefits of a comprehensive reform package. IMF Working Paper WP/18/60 (Washington: International Monetary Fund).

Bank of Italy. (2012). L'efficienza Della Spesa per Infrastrutture. Papers presented at a workshop held on 28 April 2011.

Barr, N., \& Diamond, P. (2011) Improving sweden's automatic pension adjustment mechanism. Center for Retirement Research.

Bloom, N., Griffith, R., \& Van Reenen, J. (2002). Do R\&D tax credits work? Evidence from a panel of countries 1979-1997. Journal of Public Economics, 85, 1-31.

Bugamelli, M., \& Lotti, F. (2018) Productivity growth in Italy: A tale of a slow-motion change. Bank of Italy, Occasional Papers n. 422.

Chudik, A., Mohaddes, K., Pesaran, M. H., \& Raissi, M. (2013). Debt, inflation and growth robust estimation of long-run effects in dynamic panel data models. Globalization and Monetary Policy Institute Working Paper 162, Federal Reserve Bank of Dallas.

Chudik, A., Mohaddes, K., Pesaran, M. H., \& Raissi, M. (2017). Is there a debt-threshold effect on output growth? The Review of Economics and Statistics, 99(1), 135-150.

Colonna, F., \& Marcassa, S. (2015). Taxation and female labor supply in Italy. IZA J Labor Policy, 4, 5.

De Mooij, R. (2008). Reinventing the Dutch tax-benefit system: Exploring the frontier of the equityefficiency trade-off. International Tax and Public Finance, 15, 87-103.

De Mooij, R., \& Keen, M. (2012). "Fiscal Devaluation” and Fiscal Consolidation: The VAT in Troubled Times”, IMF WP/12/85. Washington: International Monetary Fund.

Doerr, S., Raissi, M., \& Weber, A. (2018). Credit-Supply Shocks and Firm Productivity in Italy. Journal of International Money and Finance, 87(C), 155-171.

Dumont, M. (2015). Evaluation of federal tax incentives for private R\&D in Belgium: An update. Belgian Federal Planning Bureau Working Paper 5-15.

European Commission. (2015). The 2015 ageing report. economic and budgetary projections for the 28 EU member states (2013-2060). European Economy, 3.

Griffith, R., Miller, H., \& O'Connell, M. (2014). Ownership of intellectual property and corporate taxation. Journal of Public Economics, 112, 12-23.

Gulen, H., \& Ion, M. (2016). Policy uncertainty and corporate investment. Review of Financial Studies, 29, 523-564.

International Monetary Fund. (2010). Italy's fiscal sustainability revisited. In IMF Country Report No. 10/157 (Washington).

International Monetary Fund. (2016a). Tax policy, leverage and macroeconomic stability. IMF Policy Paper, October (Washington).

International Monetary Fund. (2016b). Fiscal policies for innovation and growth. Fiscal Monitor, April (Washington).

International Monetary Fund. (2019). Reforming Italy's social welfare system and lowering taxes on labor: some considerations. IMF Country Report No. 19/41 (Washington).

Kangur, A. (2018). Competitiveness and wage bargaining reform in Italy. IMF Working Paper WP/18/61 (Washington: International Monetary Fund).

Keen, M. (2013). The anatomy of the VAT. National Tax Journal, 66, 423-446.

Kohli, M., \& Arza, C. (2011). The political economy of pension reform in Europe. In R. H. Binstock \& L. K. George (Eds.), Handbook of aging and the social sciences (7th ed.). Oxford: Elsevier.

Kumhof, M., Laxton, D., Muir, D., \& Mursula, S. (2010) The global integrated monetary fiscal model $(G I M F)$-Theoretical structure. IMF Working Paper Series, WP/10/34 (Washington: International Monetary Fund).

Medeiros, J., \& Schwierz, C. (2015). Efficiency estimates of health care systems in the EU. European Economy Economic Papers, vol. 549, June.

MEF. (2014). 2015-round of EPC-WGA projections—Italy's Fiche on pensions.

Mohaddes, K., Raissi, M., \& Weber, A. (2017). Can Italy grow out of its NPL overhang? A panel threshold analysis. Economics Letters, 159(C), 185-189.

OECD. (2015a). “Economic survey of Italy”, February. Paris: OECD.

OECD. (2015b). Pensions at a Glance 2015: OECD and G20 indicators. Paris: OECD.

Pellegrino, B., \& Zingales, L. (2017). Diagnosing the Italian disease. Working Paper 23964, National Bureau of Economic Research.

Queisser, M., \& Whitehouse, E. (2006). "Neutral or fair? Actuarial concepts and pension-system design. OECD Social, Employment and Migration Working Papers, No. 40 (OECD Publishing: Paris). 
Reinhart, C. M., \& Rogoff, K. S. (2010). Growth in a time of Debt. Working Paper 15639, National Bureau of Economic Research.

RGA. (2016). Le tendenze di medio lungo periodo del sistema pensionistico e socio- sanitario. Department of the State Accountant General, Ministry of Economy and Finance, Report No. 17 (July).

RGA. (2017). Le tendenze di medio lungo periodo del sistema pensionistico e socio- sanitario. Department of the State Accountant General, Ministry of Economy and Finance, Report No. 18 (September).

Saez, E., Slemrod, J., \& Giertz, S. (2002). Optimal income transfer programs: Intensive versus extensive labor supply responses. Quarterly Journal of Economics, 117, 1039-1073.

Settergren, O., \& Mikula, D. B. (2006). The rate of return of pay-as-you-go pension systems: A more exact consumption-loan model of interest. In R. Holzmann \& E. Palmer (Eds.), Pension reform: Issues and prospects for non-financial defined contribution. NDC) schemes (Washington: World Bank.

SSA. (2016). Social security programs throughout the world: Europe, 2016. SSA Publication No. 13-11801.

Toro, J., Story, T., Hartnett, D., Russell, B., \& Van-Driessche, F. (2015). Enhancing governance and effectiveness of fiscal agencies. IMF Report, December (Washington: International Monetary Fund).

Tyson. (2014). Reforming tax expenditures in Italy: What, why, and how? IMF Working Paper Series, WP/14/7 (Washington: International Monetary Fund).

Publisher's Note Springer Nature remains neutral with regard to jurisdictional claims in published maps and institutional affiliations. 